Lessons from the Russian Meltdown: The Economics of Soft Legal Constraints

\author{
By: Enrico Perotti
}

Working Paper No. 379

March 2001 


\title{
Lessons from the Russian Meltdown \\ The Economics of Soft Legal Constraints
}

\author{
Enrico Perotti \\ University of Amsterdam and CEPR
}

March 2001

\begin{abstract}
$\underline{\text { Abstract }}$
On August 17, 1998, Russia defaulted on its domestic public debt, declared a moratorium on the private banks' foreign liabilities which was equivalent to an outright default, and abandoned its exchange rate regime. The depth of the Russian meltdown shocked the international markets, and precipitated a period of serious financial instability. It is important to understand the roots of such a crisis to learn about possible lessons on both issues of bank supervision and international stability.

While the visible cause of the crisis was an unsustainable fiscal deficit coupled with massive capital flight, the critical question concerns the origin of such circumstances. This paper argues that the structure of individual incentives in the Russian legal context, compounded by the exceptional support granted by international institutions to Russia, explains the cycle of nonpayment, capital flight and fiscal unbalances leading to the dramatic 1998 crisis. We offer an interpretative model of noncompliance, cash-stripping and rational collective nonpayment which led to the fiscal and banking crisis and ultimately to a complete meltdown. In our view, the banking sector was already insolvent prior to the crisis, and contributed directly and indirectly to it. The last section of the paper puts forward a radical medium-term policy proposal for a stable banking and payment system for Russia. Russia needs to create a basic foundation for savings and intermediation by asset restrictions and market segmentation, crude but effective rules used in all underdeveloped systems to restrain asset stripping and opportunism. Concretely, we propose a cautious extension of deposit insurance away from the monopolistic Sberbank and towards a narrow banking layer. The proposal also proposes measures to restore charter value in the commercial banking sector.

I thank Jerome Sgard, Charles Wyplosz, Erik Berglof, Julian Franks, Tatiana Paramonova, Michael Fuchs, Bill Alexander, Julia Shvets, Stijn Claessens, Marina Malyutina, and participants at presentations at the Economic Policy Panel in October 2000 in Paris, at the EBRD, the IMF, the London School of Economics and ECARES. Work on this paper has been written under the auspices of my policy work at RECEP in 1997-2000, supported by the TACIS program of the European Commission. The paper has drawn from the chronology of events in Perotti-Sgard (2000).
\end{abstract}




\section{Introduction}

On Monday August 17, 1998, the Russian authorities unilaterally declared a moratorium on all rubledenominated public debt, froze for a three-month period all foreign obligations of the domestic banking sector; this amounted to a de facto complete default by the government and the banking system. The ruble rapidly lost two third of its value vis a vis the dollar (see Figure 1), while a dramatic liquidity crisis and massive bank runs ensued.

During the following weeks the shock created by these measures developed into a full-scale international crisis of confidence, with credit spreads widening dramatically in all markets and briefly raising doubt on global financial stability. The shock waves were so strong because almost no one, not even among the most skeptical observers, had anticipated such a complete, utter collapse ${ }^{1}$.

The scale and scope of the Russian financial collapse, not to mention its speed, has challenged observers to seek a specific model of financial behavior for the Russian economy. This paper will argue that interpreting the Russian crisis requires an investigation of the distorted nature of underlying microeconomic incentives which led to such a stupefying meltdown (Graph 1$)^{2}$

It has been argued that the Russian crisis followed a conventional fiscal crisis; and that the resulting government default and devaluation were the main causes of the banking collapse (Popov, 2000). We will argue instead that while macroeconomic factors were the visible final causes of the collapse, the interesting question concerns the causes of the underlying behavior which produced such imbalances and thus are the ultimate roots of the crisis.

Essentially, this paper claims that overwhelming incentives to strip cash out of all old and new Russian institutions (banks, private and state firms) led to a diffuse nonpayment culture, and fed a frantic flow of capital flight throughout the reform period. The government was both unable and unwilling to control such a process. Collective noncompliance reduced policy options dramatically; moreover, the political leadership needed the support of special interests to remain in power, and allowed them a free rein in plundering and in capital flight. As a water tank full of holes, Russia hemorrhaged cash faster than what could be pumped in

\footnotetext{
${ }^{1}$ In the end, only a firm intervention by the Fed culminating in the rescue of the overexposed LTCM hedge fund restored confidence.

${ }^{2}$ There are two main interpretations of financial crises. A first approach sees them as the result of irrational investors first running up prices excessively, then fleeing en mass upon flimsy news (e.g. Radelet and Sachs, 1999); the second approach sees them as the ultimate result of accumulated unbalances, emerging endogenously due to serious weaknesses in the underlying legal and institutional framework, too long sustained by implicit guarantees (Krugman, 1998). We place the Russian crisis squarely in the second category.
} 
by foreign government and institutions, keen to contain a communist reversal, or by foreign investors playing a few hands at Russian roulette.

During the years of transition, Russian enterprises and banks effectively moved from soft budget constraints to soft legal constraints. The lack of a reliable public enforcement was in part the result of the political control inheritance of Soviet Russia, ${ }^{3}$ when legal rules were subject to arbitrary changes and constant ex post bargaining, and in part in the failure of early transition policy, which reinforced a collective attitude to inertia. Thereafter, the settlement of obligations became a matter of private bargaining, where rules and agreements mattered less than the relative strengths of the parties involved.

Special interests managed to capture both privatization and later stabilization policy. According to Shleifer and Treisman (1999), allowing powerful insiders to capture large rents was a necessary political compromise to remove resistance to reform by those which were able to block its progress. Yet in any pact with the devil, it is unclear who sets the rules. Similarly to privatization, the supervision of banks, the creation of the public debt market, stabilization policy, and finally the provision of currency hedges for foreign investors, were all implemented in a compromise with a powerful banking lobby which granted bankers major opportunities to capture resources from the state, from savers and foreign investors, without exposing them to any binding "rules of conduct". While "buying in" insiders allowed to proceed with quick progress of formal privatization and liberalization policy, it granted such powers to an insider managerial class and banking elite to the point to relinquish the capacity to control the reform process.

It would be desirable to be able to offer concrete evidence of massive cash-stripping and illegal capital flight; such data, of course, is by definition unavailable and, in the case of Russia, positively dangerous to collect. Our strategy is to offer different elements of circumstantial evidence which together draw a consistent picture.

An important conclusion we draw is that the foundations of the Russian financial system were long undermined by perverse incentives, and its final insolvency fed the collapse rather than being a consequence of it. The banking system was never a serious intermediating channel of funds to the real sector; banks failed to provide safe and timely payment services. In contrast to the stable situation in Central Europe, where deposits became accepted as a form of savings, in Russia (and in the CIS) the amount of cash in circulation rose throughout the nineties from a fraction to over four times total deposits, far above Central European values (Tang et al, 2000). Russian banks were often kept as empty boxes in which liabilities

\footnotetext{
${ }^{3}$ This tradition of arbitrary abuse of power pre-dates the 1917 revolution.
} 
accumulated and stripped cash was promptly sent abroad, whitewashing its ownership in the process. Banks also raised foreign debt whenever possible, to further leverage the outflow. While Western institutions and government poured over 100 billion dollars into Russia (of which around 20 billion via IMF loans), conservative estimates of capital flight up to 1998 exceed USD 136 billion.

Yet capital flight was a rational, if perverse and corrupt, response to the institutional failure of the postSoviet reforms, and was exactly the specular counterpart of the nonpayment problem.

The main fact consistent with our view is that unlike more traditional crises, capital flight did not accelerate dramatically before the collapse. Rather, capital escaped at an enormous but steady rate throughout the nineties, and even during 1995-1997 stabilization period, a time of large trade surpluses and high real rates (see Figure 2). This is prima facie evidence that the fiscal crisis and the resulting devaluation were the final consequence of steady, structural outflows rather than mirroring a progressive budget deterioration. In this paper we seek to explain the microeconomic causes of such steady outflows in terms of the failure to establish a proper structure of legal enforcement.

Yet other transition and developing countries faced the same institutional problems that Russia faced. Why was the crisis in Russia so sudden and so deep ? Similar arguments, based on opportunism and crony capitalism, have been put forward for the Asian crisis as well. ${ }^{4}$ In what way is Russia different from, say, Ukraine or Bulgaria, or even Indonesia?

Russia's fall has been spectacular in large part because it had been artificially delayed. Its nominal reforms were for too long supported by international financial institutions and Western countries keen to see a proWestern stand survive in Moscow. Western governments were generous lenders; both the 1996 and the 1998 IMF loan programs were clear examples of concessionary support, and sent powerful signals to private investors. Most other countries are not allowed such a long run, and their failures are thus less spectacular. In addition, in few countries were the short incentives to strip cash at all cost as strong, and the risk of punishment as feeble, as in Russia in the late Yeltsin period, with a gross currency overvaluation and a weak political center.

In such a context, the overwhelming focus of Western assistance on monetary stabilization, funded by foreign aid and loans, was terribly misplaced, and suggests an inappropriate policy approach. A more appropriate focus would have been to press for stricter contractual discipline in the new (the banks) and

\footnotetext{
${ }^{4}$ There the macroeconomic picture looked quite different; a large trade deficit, a much better fiscal position, large domestic banking systems, and especially a high investment and growth rate. Yet the described massive financial misallocation (Corsetti,
} 
"reformed" institutions (the Central bank and the state enterprises), and to close the many "legal" avenues for shameless appropriation as preconditions for any lending. ${ }^{5}$

To be fair, the IMF and the World Bank came under intense political pressure to support Russia at any cost. They were forced to gamble, in the hope that stability would last long enough so that over time a microeconomic basis would be built. Yet the massive support they gave to support the ruble actually reinforced the short-term incentives to appropriate and export capital, by creating an unsustainable degree of ruble overvaluation. ${ }^{6}$

This paper starts with a brief chronology of the main trends in the banking and enterprise sectors during the period 1992-98. It then describes the basic incentives and a model of collective moral hazard behavior of widespread cash-stripping and insolvency, and discusses how this precipitated the inevitable crisis of August 1998 and how it helps explain some of the surprising consequences of the crisis. The last section discusses a radical policy proposal, based on the interpretation presented, for the medium-term restructuring of the hollowed-out banking sector within a framework of crude but more reliable regulatory constraints.

\section{Section 1 A brief history of Russian banking, 1992-1997}

\section{The emergence of a new financial system}

After a period of partial and inconsistent reforms under Gorbachov, the demise of the Soviet Union in the fall of 1991 opened the way for an ambitious "shock-therapy" program, launched in January 1992 along lines comparable to the Polish 1990 plan. The Gaidar government tightened central bank credit in January 1992 in order to encourage microeconomic restructuring in the wake of price liberalization. The impact was a serious credit crunch; the critical phase of this policy required consistency in resisting pressures for reflation and compensatory bailouts, ultimately forcing adjustment. In the Russian case, the adjustment response was insufficient, and arrears mounted at a dramatic rate. The policy collapsed by summer, when unpaid trade bills were three times as large as total bank credit, with a massive bailout funded by money printing. The temporary bailout validated collective inertia and led to new cycles of arrears in 1992, 1993, and 1994. Domestic savings were wiped out by the resulting inflation.

Pesenti and Roubini, 1998), supported by moral hazard by foreign investors (Corsetti, Pesenti and Roubini, 1999), is quite similar.

${ }^{5}$ The new mandate suggested for the IMF would reduce its relative novel role in promoting microeconomic reforms and limit it to provide short term liquidity to countries satisfying certain criteria. Its likely effect would be to severely limit the number of countries which would qualify for IMF support, and increase pressure to perform legal and institutional reform as a precondition for intervention as opposed to loan conditionality . 
A cycle of tightening central bank credit, lack of adjustment leading to illiquidity, an explosion in trade and wage (and increasingly tax) arrears, output disruption, and finally reflationary money injections, led to high inflation over the period 1992-1994, with monthly inflation rate between 5 and $25 \%$.

What explain the failure of this early stabilization attempt? We believe that it was the result of the choice made by a critical mass of enterprises facing a tough restructuring decision. In deciding whether to restructure or not, each manager had to take into account his adjustment costs as well as the chance of a bailout of insolvent units. This latter depended critically on the expected number of inertial responses, as a critical mass of insolvent firms creates an insurmountable political pressure for relief (Perotti, 1998). Thus the individual decision depends on the decision of others, as well as on the credibility of the government. Since this systemic policy shift implies a collective response with strategic complementarity, multiple equilibria were possible: the degree of ex post enforcement of financial obligations was endogenous to the collective compliance response by others. Russian expectations about the likely behavior of other units (in part a function of cultural and historical experience, ${ }^{7}$ as well as a rational assessment of median adjustment costs) clearly suggested a deep lack of confidence in the capacity of the system to sustain the changes required by the tight credit policy. ${ }^{8}$

The cyclical bailout policy extinguished itself at the point when the real size of each bailout declined over time, in part due to more rapid inflation surges.

A new financial sector developed under the laissez-faire entry policy which started in 1989, when capital requirements for a banking license were ridiculously low, while monitoring and supervision were at best formal. The number of Russian banks went from fewer than 10 to over 2500 in the early 1990s. Many banks simply performed cash management, capital flight and whitewashing services for enterprises or shadowy organizations (pocket banks), and were at first active mostly in speculating against the ruble. At a time of high inflation, banks could also hold on to transfer payments for clients while earning the float, which corresponds to the private collection of a large inflation tax. Non-bank institutions developed rapidly into pure Ponzi schemes, such as the large MMM scheme which collapsed in 1994. Some well-connected banks richly benefited from political support, with profitable assignments to manage the balances of State authorities, or to finance certain expenditures.

\footnotetext{
${ }^{6}$ The visible weakness and incompetence of the externally supported government also reinforced domestic concerns for future political upheaval.

${ }^{7}$ Passive resistance was a pattern already developed under central planning, when unrealistic diktats from the center could be often resisted by collective sluggishness.
} 
Stabilization policy from 1995 onward froze the printing presses; at that point there was a last chance to tighten financial discipline. In contrast, a weak government, prey of special interests, only shifted to a different form of ex post laxity; it did not manifest itself in looser money, but looser rules, condoning nonpayment and theft and stoking trouble for later.

From 1995 onwards, the number of banks fell under the regulatory tightening of Mrs. Paramonova's more rigorous policy at the CBR. The more obvious short-term players went under with the progress of disinflation, which she pursued rigorously. It was probably at this critical stage that the last chance for financial discipline was lost to the pressure of special interest. After the removal of Paramonova by the Duma in 1996, supervisory reform de facto stopped, and returned to formalistic controls. Capital increases required by regulation were achieved via accounting tricks, such as using funds borrowed from the bank itself.

While banks were allowed to operate insolvent, under either an ineffectual, or incompetent, or co-opted Central Bank, they were hardly alone. Once stabilization policy put a stop to the destruction of real obligations via inflation, enterprises rapidly ran up large amounts of trade and wage arrears (see Figures 3 and 4); tax payments, largely raised from enterprises, went massively overdue; citizens did not pay utilities; even the government itself failed to pay for pensions and purchases.

In 1997 the economic growth rate was marginally positive for the first time in the 90s, thanks to falling interest rates on the back of strong Western financial inflows. Nominal stabilization was obtained by shifting from inflationary financing to issuing ruble-denominated public bonds (at first just to a few Russian banks at extremely high yields, and later to foreign institutions. In 1997 the economic growth rate was marginally positive for the first time in the 90s, thanks to falling interest rates on the back of strong Western financial inflows. Thanks to foreign exchange stabilization, intermediated ruble assets for the first time offered better returns than mattress dollars. This made possible the build-up of a small deposit base by a limited number of private banks, competing with the former retail monopoly Sberbank, the sole bank enjoying deposit insurance. In 1997 there were brief signs of some growth in intermediation to enterprises, although most lending was extended either within bank-controlled groups or along personal relationships. The stock market boomed, as foreign brokers interpreted the low price-to-earning ratio of Russian stocks as a buying opportunity, rather than a reflection of the non-existent protection of minority rights.

\footnotetext{
${ }^{8}$ Countries in Central Europe with a historical memory of individual responsibility under a classic rule of law have done better
} 
This superficial impression of a window of opportunity was actually doomed to fade rapidly. Russian firms kept avoiding tax, wage and loan payments, even when able to perform them. Capital flight Under the pressure of increasing budget deficits caused by tax arrears and a weak oil price, investment in the GKO-OFZ government bond market, initially reserved to a small group of insider banks, was opened to foreign investors. These bonds paid very high rates in real terms as inflation fell, which further encouraged cash stripping and tax arrears. Capital flight of stolen cash, on the other hand, did not diminish. Banks took advantage of stabilization and the IMF support to accumulate dollar liabilities to fund their GKO purchases; their net profit from the interest rate differential were quickly exported. Yet banks kept reporting a strong balance sheet.

The final example of private capture of regulation, which in the end worsened dramatically the crisis, was the transfer of the provision of forward contracts on the forex exchange in January 1998 from the Central bank to the commercial banking sector, arguing that dollar hedges were necessary to retain international investors in Russia. Russian banks rushed to offer forward contracts to foreigners eager to hedge their ruble risk on a massive scale, capturing the interest rate differential with no investment at all while the exchange rate held, while at the same time offering insurance they had no plan to honor.

The difficulty in refinancing the booming stock of short term public debt was compounded by the Asian crisis in late 1997. A new Russian government was brought in March 1998, on a mandate to restore fiscal responsibility. As it turned out, its few reforms went unimplemented, tax collection did not improve, banks were emptied, and capital kept flowing steadily abroad. ${ }^{9}$ As it turned out, its few reforms went unimplemented, tax collection did not improve, banks were emptied, and capital kept flowing steadily abroad. Yet even the average Russian turned out to be a bit naïve; Perotti and Sgard (2000) argued that Russian bond markets had envisioned a devaluation, not a complete default. Only a few influential Russian bankers managed to capture and abscond the last rounds of dollar reserves from the Central Banks just before the collapse. ${ }^{10}$ At that stage they managed to convince the government to announce as well a 90 -day foreign debt moratorium on all loans and currency forward contracts as part of the maneuver, allowing them a de facto right to default for the time necessary to remove the last assets left within the banks.

\footnotetext{
in reversing collective inertia or collusion than countries with a longer tradition of central planning.

${ }^{9}$ Yet even the average Russian turned out to be a bit naïve; Perotti and Sgard (2000) argued that Russian bond markets had envisioned a devaluation, not a complete default. Only a few influential Russian bankers managed to capture and abscond the last rounds of dollar reserves from the Central Banks just before the collapse.

${ }^{10} \mathrm{Mr}$. Potanin, the owner of the major private bank Uneximbank, revealed in November 1998 that some bankers knew a few days in advance about the free floating of the ruble on August $17^{\text {th }}$.
} 


\section{Section 2 The players of the cash-stripping economy}

We review more in details the incentives and forms of cash-stripping in the privatized enterprises; we then discuss the general consequences on demonetization and on the fiscal budget. At the end we then discuss the critical role played by the banks.

\section{Enterprises}

Mass privatization created private firms controlled by insiders. In a grand political bargain to buy out opposition to privatization (Shleifer, 1992), ownership of most enterprises became controlled by insiders, with managers in firm control (often thanks to share purchases or pooling of shareholdings from workers under the control of managers).

One consequence of poor legal enforcement is that control rights are much more valuable than contractual and property rights (Modigliani and Perotti, 1998; Bebchuk, 1999). Control generates access to cashappropriating activities and thus to the purchase of political support, which is essential for protection from enforcement or to buy favorable legislation. In the end, it is not lack of legal text, but capacity or willingness to enforce, which makes all the difference (Gelfer, Pistor and Raiser, 2000).

Whether these entities would establish themselves as long-term institutions depended on whether there existed incentives to restructure, by retaining cash flow and reinvesting it internally. ${ }^{11}$ This did not happen in Russia: owner-managers of all types of institutions (whether firms or banks) had poor incentives to restructure their productive activities and reinvest internally.

Why were economic incentives so distorted for enterprise management ? Restructuring production offered low returns and high risk, due to the fall in demand, the novelty of a competitive market, and direct threats to property rights. Corporate profits were exposed to external predation, either by the tax administration, criminals and racketeers, unpaid clients or workers, or even the Communists in the Duma. In this environment managers protected their own interests against predation by stripping and transferring cash, rather than investing it in value-adding activities. As the Romans said, "Pecunia non olet": cash has no odor. Cash is anonymous, easy to transfer, and difficult to track and tax. ${ }^{12}$ The discretionary power to swap

\footnotetext{
${ }^{11}$ In all countries the real sector relies on internal finance as the primary source for re-investment and capital accumulation; this is particularly true in developing countries.

12 This problem was made more acute by a legal framework in which someone who acquires illegally obtained property in a formally correct procedure is recognized as the owner. Thus asset-stripping needs only one intermediate step to legalize the transaction.
} 
assets at arbitrary prices, produced greater cash flow than what managers could hope to gain as valueoptimizing shareholders. ${ }^{13}$

Why did privatization fail to break this pattern? First, it granted insiders control but fuzzy property rights. Second, it left no external threat to the manager in the case of failure. This created extreme incentives for the opportunistic appropriation of cash-flow rather than medium-term restructuring. Yet privatization has produced better results in other countries with weak incentives, such as in the Czech Republic. The Russian case suggests a loss of regulatory control over the process, in part due to the excessive capture of power by the insiders.

The most spectacular example of the ability of insiders to capture control of large rents in exchange for political support was the debt-for-share deal, negotiated at a time when the main bankers sat in the government. Via an obscure secured loan, control of the best industrial and natural resource companies was captured by a few influential banks in 1994, creating a number of Financial Industrial Groups (FIGs). ${ }^{14}$

\section{The nonpayment culture and the de facto seniority of claims}

In an environment where cash money is hoarded and where the settlement of debts and contracts is mostly a function of bargaining, a sort of de facto seniority of claims emerge which has little connection with the de jure contractual seniority.

In the actual seniority of claims in Russia, what counts is first the capacity to impose powerful sanctions, often greater for criminals over legal entities, or local government over federal government. Next comes the implicit power derived from reciprocal dependence, such as links to trading or financial partners, or political allies. Foreign investors belong to this category only as long as they may offer new funding in the future. Next comes the formal authority of government.

The de facto most junior creditors, with the least bargaining power, are expectedly the workers' retail depositors and minority shareholders. Wage payments do not rank high among the priorities of Russian managers; their capacity to run up wage arrears is in fact crucial to understanding how the Russian

\footnotetext{
${ }^{13}$ Selling out loss-making enterprises to external investors was also hardly profitable, given the difficulty of seizing control against other insiders. There have been several episodes in which workers and managers successfully resisted raids by armed Interior Ministry troops to seize industrial premises on behalf of external investors.

${ }^{14}$ Large industrial-financial groups, common in underdeveloped financial systems, certainly owe their influence to political support. yet they may provide governance and an internal capital market to alleviate credit constraints. Empirical research on Russian FIGs (Perotti and Gelfer, 2001) has shown that while group firms were better managed, cash flow from cash rich group firms was reallocated on a massive scale, and may have been shifted outside the group.
} 
economy could maintain a tight monetary policy in the face of massive insolvency. Unlike, say, Latin America, it was possible for both the government and enterprises to ignore legitimate payments to workers, savers, and pensioners at the time of tight money. In no other industrialized country have workers suffered such a degree of nonpayment with such resignation (Earle, 1998). The diffuse cynicism of Russian citizens, and their mistrust of authorities and reform, cannot come as a surprise.

\section{Taxation}

Liabilities to tax authorities in Russia have enjoyed a variable status, contingent on political circumstances. While payments to central tax authorities depend on the perceived political strength of the government, payments to local government were usually more binding. As for other liabilities, the ability to resist tax payments depended on the size of the enterprise and its political strength, especially for firms with strong local presence or for nation-wide players, such as Gazprom and the large electricity networks.

Uncontrolled opportunistic behavior can have systemic effects, when moral hazard is reinforced by its diffusion; it can then undermine general contractual discipline, overwhelm legal enforcement, and lead to a complete loss of control over taxation.

The sketch of a model of collusive behavior can illustrate this point. Consider the incentive of a Russian firm to delay payment of its tax liabilities. There may be some costs due to the risk of strong enforcement measures. This risk is likely to diminish as more firms fall in arrears, as tax authorities face a greater task of collection, and perhaps more political resistance. (While there are penalties for late tax payment, in theory quite stiff, final settlement in Russia is almost always a matter of bargaining.)

As in the case of financial stabilization, the perceived risk of noncompliance depends on the perception of what other firms are doing. At the same time, the reward of delaying payment was represented by either the prospect of capital flight or by the yield on GKOs. This further reinforces the benefits of tax resistance: the lower the tax revenues, the larger the budget gap, the stronger the need to issue bonds, and the higher the GKO yield. Thus, under expectations of widespread tax resistance, the costs of delay fall and its rewards rise in the perceived number of firms in tax arrears. ${ }^{15}$

In fact, tax revenues as a percentage of GNP continued to remain weak throughout the period (Figure 5). The last days of the failing Chermomyrdin administration were marked by a massive expansion in tax surrogates (offset payments, e.g. unpaid deliveries to regional government), allowing enterprises to erase

\footnotetext{
${ }^{15}$ All this suggests that resolving the problem of massive tax evasion and capital flight requires in Russia a strong central political leadership in place. This seems confirmed by the improved discipline under the Putin administration.
} 
overdue taxes, and were matched by rising GKO rates. Even as the new government of Kirilenko tightened fiscal rules, and closed the legal loopholes of tax offsets, payments in cash kept stagnating, reflecting the impotence and the political weakness of the government (Ivanova and Wyplosz, 1999).

The collusive model applies equally naturally to compliance to legal reform or to enforcement of prudential rules in the banking sector. Massive non compliance overwhelms any (if any) ability of policy-makers to address it ex post. Just as monetary authorities come under extreme pressure for financial relief, and tax authorities fail to enforce payments, thus validating nonpayment, legal reform cannot be enforced in the face of collective noncompliance. The result is to induce either an explicit financial bailout or a legal bailout with massive socialization of losses. This effect, termed by Janet Mitchell (1998) the "too-many-to-fail effect», has been modeled by Perotti (1998) in the context of financial arrears, by Roland and Verdier (1994) for privatization, and by Mitchell (1993) for bankruptcy.

In a situation of no societal constraints to the abuse of power, the question is: what is the response of powerless citizens and firms? The rational response in Russia has been collective inertia and passive resistance on a massive scale. An unreliable legal environment and collective inertia reinforce each other. In terms of financial behavior, asset-stripping at the top is matched by the passivity and systemic non-payment and illegality.

The inability of the federal government to enforce fiscal discipline, including local government, and its failure to pay suppliers, contributed massively to the growth of barter. The state was forced to accept tax payments in kind; "offset operations", where overpriced deliveries to local government were accepted as fiscal payments, weakened fiscal credibility (see Ivanova and Wyplosz, 2001). ${ }^{16}$

The ability to ignore payments to suppliers depends on their importance and size. Russian firms need to maintain good relations in order to secure essential inputs; yet such is the value of cash that their preferred form of payment has been via barter transactions, leading to an unprecedented degree of demonetization of payments.

Similar experiences have historically occurred in a war or hyperinflationary conditions. In contrast, barter grew steadily as inflation fell in 1994-1998 ${ }^{17}$. Figure 6 illustrates its dynamics, with a sharp acceleration in coincidence with monetary stabilization: from $20 \%$ in 1995 it rose to two-third of trade during the first half

\footnotetext{
${ }^{16}$ Political changes which are widely seen as weakening the center can thus have a disproportionate effect on tax compliance if they become a focal point for expectations of a weaker bargaining position by the federal government.

17 While there is no consensus on the causes, some facts are clear. It is associated with large, privatized firms; it is more diffused in agriculture and industry, especially energy utilities, than in services; strong real good competition tends to be linked with less barter.
} 
of 1998, in tandem with tax and wage arrears. It is, jointly with the explosion in cash holdings, further evidence that cash-stripping took precedence on productive activity. Evidence to this effect is that barter rose with real interest rates and with ruble overvaluation, the opportunity cost of timely payment (Figure 7). 18

A related view is that barter is a form of collateralized trade credit, which emerges when there is no credible liquidation threat for insolvent firms. Marin and Schnitzer $(1999,2000)$ argue that barter supports trade between tightly integrated firms, when credit enforcement is unreliable. Thanks to mutual bargaining power, trading via barter goods provides a form of collateral which limits the buyer's ability to resist payment. In terms of our argument, barter offers the sole transacting solution when managers have overwhelming incentives to strip any cash.

Demonetization extended to retail payments and even cash savings, with estimates of dollar cash holdings ranging from equal to thrice ruble holdings. The structural delay in payment transfers by banks and their general unreliability contributed specifically to this phenomenon.

We now come to discuss the role of banks.

\section{Banks and Banking Supervision}

Bankers retained only a tiny personal claim on assets, but held discretionary control over their allocation. Connected lending (namely, loans to insiders and friends) was often an outright transfer; the cash would be lent to an empty box firm which would pass it on and ultimately vanish, leaving no trace of its owners. Cash also left the banks via purchases at face value of worthless securities from obscure companies, often located abroad. Box 1 shows an example of such transactions, drawn from an actual case.

\footnotetext{
${ }^{18}$ Ivanova and Wyplosz (1999) find that both higher monetary growth and higher interest rates are correlated with higher barter.
} 


\section{Box 1: An anedoctal account of cash stripping}

The following is an account of a common technique to strip funds used by large Moscow banks around the August crisis.

1. There exists a fairly liquid market for the promissory notes issued by some obscure organizations. They trade at $0.15 \%$ of their nominal value. Most popular were the notes issued by some Federal Energy Systems. It was obscurely alleged that these notes were guaranteed by the RAO United Energy Systems of Russia. The market capitalization in nominal terms of these notes exceeds the annual Russian GNP.

2. An offshore company XXX buys these notes at the market price and then puts them on its balance at the nominal valuation. A Russian company would have to value them at the historical cost (i.e. at the market value).

3. The Russian Bank ZZZ and XXX write a Contract of Exchange in which ZZZ issues promissory notes secured by some real assets. These are exchanged for the "funny" notes owned by XXX. The upshot is that the rate of exchange corresponds to the face value of the "funny" notes. A Contract of Exchange also avoid tax liabilities.

4. Optional. A new Russian bank YYY is set up. It is owned by the owners of ZZZ but not related to ZZZ in any formal way. YYY issues its unsecured promissory notes and exchanges them for the secured notes of ZZZ in possession of the offshore company XXX.

5. The offshore company $\mathrm{XXX}$ is liquidated.

6. Conclusion: the old bank ZZZ is left with all the liabilities and with promissory notes valued at their face value but in essence worthless. The newly created bank YYY is free of liabilities and has all the real assets. 
On paper, the Russian Central Bank progressively adopted Western supervisory standards. On paper, Russian banks were highly capitalized in 1997-98. In practice, the tighter supervisory policy of bank closures was abandoned once Mrs. Paramonova was removed from her position as Governor by the Duma, presumably under pressure from the banking lobby. The Central Bank has been a fictional regulator since then.

Bankers have enjoyed tremendous political clout, either via their cash-rich lobbying or by virtue of their control over the media. One example of their political power is reflected in the incredible story of Russian bankruptcy law. The first general bankruptcy law in 1990 was extremely pro-debtor and thus toothless. Later legislation amended the text, although the capacity to implement the law remained minimal: removing insiders from control turned out to be almost impossible ${ }^{19}$. Furthermore, under intense lobbying from the cash-rich banker lobby, the law explicitly stated that it would not be applied to banks; a new federal regulation would apply to this sector. Curiously, no such federal law on bank bankruptcy was ever passed until the 1998 crisis. Since the original law ruled out any clear authority of the CBR, the result is that the most indebted and vulnerable sector in the Russian economy could thrive in the absence of any serious threat of exit. De jure, Russian banks could not go bankrupt. ${ }^{20}$

It is not surprising that most banks were kept as legal shells full of liabilities rather than built up as credit institutions. Increasingly, as the eventual collapse was nearing, banks sought to maximize their leverage and exposure to the foreign exchange; the cash flow generated by such speculation was taken out while liabilities (contingent on ruble devaluation) piled up. Yet as of early 1998, Russian banks were reporting capitalization rate above $10 \%$ of assets, the modern equivalent of the façades of the houses in the famous Potemkin village.

Paradoxically, the crisis has produced a negative impact on the degree of prudential enforcement and bank closures. As evidence, Table 1 illustrates the rate of bank closures before and after the crisis. The number of liquidated banks has fallen, just as their insolvent status has become obvious. The initial explanation that the sheer number of failed banks overwhelmed the CBR does not hold any longer. The few CBR officers who tried to force liquidation have been countermanded and resigned. Failed bankers are allowed to escape repayment and even liquidation, with no legal consequences. Most incredibly, some extraordinarily bankrupt banks whose license had been withdrawn around the time of the crisis have managed to have it returned.

\footnotetext{
${ }^{19}$ In more recent days, a tighter insolvency legislation has been used by local politicians to capture control over enterprises.

${ }^{20}$ The consequences were visible after the crisis, when some feeble attempts by the CBR to seize control of failed banks were thrown out in court. Legislation was only passed in 1999 under intense IMF pressure, yet hardly any bank has been closed since.
} 
What we consider the main direct evidence of the role of the banking system and its insolvent status even before the crisis comes from a major bank audit performed in the fall of 1998 by Western experts in the 18 most insolvent large Russian banks. Poor lending, often to strip assets in favor of connected parties, accounted for over a third of capital losses. (Loan losses, hidden for years, more than quadrupled to $42 \%$ of all loans in 1998, and estimates run as high as 70\%). The fall in the ruble caused another $25 \%$ of losses; yet this reflected the banks' extreme speculative exposure to the exchange rate, built up deliberately before the crisis. In comparison, losses due to the fiscal default were moderate. In fact, the default on GKOs accounted for less than $13 \%$ of losses.

This is hard at first to square with the balance sheet data on the exposure of Russian banks, which indicates a much larger stock of GKO debt relative to their net exposure to foreign obligations until a few months before the crisis (see Figure 8). The truth is that the banks' exposure to the dollar rate was much higher, and more leveraged, by the steady sale of forward dollar contracts to foreigners in the year before the crisis, building up a huge exposure to contingent (i.e. off-balance sheet) dollar liabilities. Table 2 illustrates the shocking forward exchange exposure that the largest Russian banks were able to build, representing up to twenty times their own (largely imaginary) capital. This allowed them to capture the large interest rate differential without any real investment nor any obligation they planned to honor. The Central Bank did not attempt any prudential control: banks were able to claim that they had "cross-hedged" their exposure by side contracts with small regional banks. De facto, the difference between the net and gross exposure was blurred.

Thus Russian banks were bankrupt even before the crisis; they were pure legal fictions used as conducts of capital flight, leveraging their speculation bets with borrowed funds.

\subsection{After the crisis}

After the crisis, massive bank runs broke out. Unsurprisingly, banks were able to refuse or delay withdrawals. While the last assets, such as office furniture, left the bank buildings, the Central Bank shifted most frozen deposit to the old Soviet savings bank Sberbank. Depositor confidence in private banks has collapsed, and Sberbank has been able to absorb $90 \%$ of the ruble savings market. No other bank but Sberbank, a clumsy and inefficient retail operation, enjoy deposit insurance.

The crisis in Russia did not have the same impact on real activity as in Mexico in 1995 and in Asia in 1997. A steep fall in production occurred immediately after the August crisis, reflecting severe disruptions in domestic trade; but a strong recovery surfaced by December and the output loss was comparatively modest. Many authors have argued that severe recessions in emerging economies are linked to financial distress and 
sharp liquidity crunches, possibly aggravated by adverse policy initiatives (see Stiglitz, Sachs, Ferri and Kang 1999, Borensztein and Lee 2000). In Russia, the ability of firms and banks to renege on their obligations, the limited development of intermediation, and the extend of barter trade contribute to explain why the financial crisis did not feed through in the real economy.

Three important elements have changed in Russia since the crisis. As the ruble overvaluation has disappeared and domestic demand has revived, the trade-off between cash-stripping and productive activity has shifted; as a result, firms have started using more conventional trade credit or even cash payments, capital flight has slowed. As a result of political consolidation under Putin, central (tax) authority has been partially restored, rising additional risks for capital flight and outright tax default. Finally, a strong oil price has boosted corporate liquidity and thus demand.

As a result of changed incentives, capital flight of export revenues has slowed down (as Figure 2 illustrates). This is remarkable in the light of the massive increase in (pre-stripped) enterprise liquidity. Clearly, the pressure to escape the ruble has subsided as the currency overvaluation has diminished; and the new political leadership has been both reassuring and conducive to greater discipline.

Further evidence that barter is associated with incentives for cash-stripping out of the enterprise sector comes from its steady fall since the crisis.

Yet capital flight persists, and the country's financial system has lost all financial credibility abroad and internally; preciously little has occurred to restart the domestic intermediation circuit. In fact, banking policy does not even appear in the list of policy initiatives undertaken in Russia under the new Putin Administration. Some Russian financial institutions may be enjoying a return of enterprise liquidity, but the system remains unreformed and extremely prone to the next crisis.

\section{Section 3 A medium term strategy for bank restructuring}

Since the August crisis, individual depositors shifted away from private commercial banks to cash or accounts at Sberbank, either by choice or by decree. This has meant the virtual implosion of the Russian banking system towards its predecessor - the Soviet-style retail monopoly. Sberbank now accounts for over $87 \%$ of all household ruble deposits and almost $80 \%$ of total retail deposits (Figure 9). Such extreme concentration, induced by a deposit guarantee, discourages competition and creates a dangerous financial and political time bomb, especially since Sberbank is now venturing into commercial lending and shows willingness to support politically favored projects. The fear is that the new government, keen to centralize control, may choose to accept once again Sberbank as the transmission-belt of central orders. 
The Russian banking system has lost almost all credibility; yet restarting domestic intermediation is indispensable to fund restructuring and essential government spending. Even though the amount of Russian savings in the intermediation process has never been large, this is still a significant loss for the economy given the scarcity of external funds currently available to Russia in the foreseeable future.

This section outlines a rather radical solution based on our interpretation of the economic incentives and lack of legal enforcement in Russia.

The serious failure of supervision over Russian banks reflects in part the limited intervention capacity in the face of the "universal bank" choice of legislation; an excessive number of licensed "banks"; shortcomings in banking legislation, due largely to the influence of the banking lobby over legislators; poor legal enforcement and the corruptibility of courts; and finally the lack of transparent Russian accounting standards. The large number of commercial banks not only overrated the CBR's supervisory capacity (and thus reduced the incentives for compliance), but also spread banking talent thin and reduced lending margins to proper borrowers. This encouraged banks to get involved in speculation rather than in traditional lending activities.

Very little has been done on banking policy since the crisis. The number of bank licenses withdrawn has been considerably lower since the crisis than before.

Some legislative steps have been taken under IMF pressure since the crisis, but their enforcement has been erratic at best. There have been cases of "zombie banks" re-obtaining a bank license via court decisions, after two years in bankruptcy proceedings and without any new capital or restructuring plan.

In addition to the legal vacuum described above, incentives to conduct proper banking business remain undermined by poor creditor rights protection. Under this system, loans in Russia are so risky that they often reflect de facto transfers to insiders, which is in fact hat most of them are. There are signs of some recovery of lending from an extremely low basis, reflecting the high liquidity in the banking sector and the improved incentives within enterprises since the devaluation and the recent surge in oil prices, little has changed to incentives, and the vulnerability of the sector to external shocks remains extreme. The large number of commercial banks not only overwhelms the CBR's supervisory capacity, but also spread banking talent thin and reduced lending margins to proper borrowers. All these factors encourage banks to engage in speculation rather than in traditional lending activities. 
Since the crisis, very little has been done on re-establishing discipline or enforcing bankruptcy of the remaining empty shells. Actually, the number of bank licenses withdrawn has been considerably lower since the crisis than before (Table 1). While legislative steps have been taken under IMF pressure since the crisis, their enforcement has been erratic at best. There have been cases of "zombie banks" re-obtaining a bank license via court decisions, after two years in bankruptcy proceedings and without any new capital or restructuring plan. The legal and prudential rules are easily circumvented or challenged. Since legislation and prudential supervision have failed to control asset-stripping in banks, only radical changes in the structure of the bankers' incentives for prudent lending will offer some chance of stability. Our proposal seeks therefore regulatory solutions which may be crude enough to be feasible, and robust with respect to opportunistic behavior. Yet for them to be actually enforced, they may need to relay once again on the creation of a strong political support by special interests. We argue that this may be necessary to gain support for their implementation, but we remain aware of the issue of the risk of their capture. In the specific proposal outlined, the cost would be a segmented and concentrated banking system, a structure, to be fair, which corresponds to the historical configuration of Western financial systems at the beginning of their development.

\section{What can be done? (Chto delat'?)}

Measures to restructure Russia's banking sector will only be successful if they take into account the problems which led to its failure. Thus, the first and foremost task of the restructuring process should be to create incentives for prudent and efficient banking among existing and potential bank owners which would persist into the future. One of the first priorities must be to recreate a foundation for the financial system, by establishing a layer of reliable banking institutions to ensure payment services and safekeeping for retail depositors.

Yet this requires also the containment of the ability of any large bank to obtain credit because of their position in the payment system and their deposit network. The legally-determined monopoly of Sberbank should be progressively diluted by additional entry of saving banks.

More specifically, the proposal is to differentiate strongly between savings and commercial banking, creating a layer of banks whose main activity would be to accept deposits and conduct payments. In order to prevent decapitalization, reckless speculation or outright cash- stripping, they will be forced to invest their balance sheet into safe assets, such as Central Bank bonds, government bonds, domestic bonds with an 
international rating, and safe foreign assets. Riskier lending would be allowed only up to the level of paid-in capital. The assets of such safe banks could not be legally swapped or pledged as collateral to third parties, to rule out asset-stripping. (In the extreme case, the assets may even be deposited with the CBR.) Safe banks may be progressively authorized to use a rising fraction of their funds to make loans or invest in real estate, so as not to exceed their capital or a low fraction of their assets. Initially, this fraction should in any case be no more than $10 \%$.

These draconian quantity rules would eliminate the risk of a bank getting involved in speculative operations or in opportunistic transactions in favor of connected parties. The supervision task of the Central Bank with respect to these institutions should be greatly simplified, since it is much easier to monitor a bank's compliance with asset restrictions than, for instance, its compliance with capitalization requirements. Glaeser and Shleifer (2001) have indicated how in circumstances when regulatory enforcement is difficult, quantity restrictions, while inefficient, may be preferred to other restrictions, easier to circumvent. It is important to view this decision in the history of credit market development in the West. Most countries started their financial development with a highly segmented banking system, with specialized institutions dedicated to specific services and product. This reduced competition at the time when it was hard to control speculation, built up specialized skills and controlled risk-shifting via asset substitutions, via strict guidelines on admissible holdings for banks. Deregulation took place progressively, as a more indirect regulatory framework and market mechanisms became strong enough. Russia's leap into universal banking was not the result of a well thought out policy, rather a bending to strong special interests.

Russia must and can evolve gradually to stages of greater financial development, but the process require some sequencing.

Narrow banks can still be profitable, despite the seemingly simple nature of activities such as handling deposits and payments. A recent study of credit institutions in the United States, known for strong competition among its retail banks, has shown that profits received by banks from fees for handling payments, keeping deposits and other client services account for over $40 \%$ of the total profit of these banks. ${ }^{21}$ A profitability study of banks in Eastern Europe (Fries et al., 1998) also showed that a major determinant of profitability for credit institutions in the region has been a solid retail base, which has allowed the banks to invest depositor funds into higher yielding government paper.

In general, Russia cannot afford a universal insurance scheme, but a partial and tightly regulated insurance scheme would be credible and help revive confidence in the system. The asset restriction of safe banks will control the risk of reckless speculation, and would allow the state to extend a credible deposit guarantee to 
other retail banks besides Sberbank. This is desirable, in order to contain the ability of any large bank to demand support because of its position in the payment system and their deposit network. Thus, the legallydetermined monopoly of Sberbank should be progressively diluted by additional entry of saving banks. The second layer of banks, the commercial banks, will not have restrictions on their assets, and will not enjoy deposit insurance. Banks in this risky layer will need to be re-licensed by the CBR to carry the name of "bank". This licensing (or re-licensing) will be conditional on significant new capital, to be set at a fairly high level so as to be initially very restrictive on entry.

The goal of a temporarily concentrated commercial banking sector is to restore profitability in proper banking operations with the few available borrowers in good standing. Research suggests that a more concentrated commercial banking sector may be safer precisely because a not excessive degree of competition maintains margins in less risky lending. This creates powerful incentives for banks to remain solvent in order to maintain their valuable operating licenses. ${ }^{22}$

Segmentation and restricted entry have been the common initial structure for the banking sectors in practically all countries at the early stage of their financial development. We believe such restrictions on competition reflect several essential reasons. The first is that initially the institutional capacity for contractual enforcement is limited, so constraints need to be crude to be easily verifiable and enforced. The second is that in these circumstances the value of a banking charter is the best incentive for the development of a medium term strategy of proper banking practices over short-term opportunistic speculation and theft. In the long run, when the supervisory capacity of the Central Bank is significantly strengthened and the threat of bank bankruptcy for failure to repay creditors becomes credible, the asset restriction in the safe layer of banks can gradually be relaxed. It will also become possible to expand the flow of resources from safe to commercial banks by allowing more interbank loans, a channel now moribund but potentially very important. Monitoring these flows on the interbank market will become a controllable instrument of supervision for the CBR.

There is an important political economy argument in favor of establishing an initially restrictive licensing and re-licensing policy. As it is often the case in Russia, any reform affects strong entrenched interests which have the ability to block it. Currently, a large number of licensed banks is little more than a burnedout shell; yet resistance to a clean-up has discouraged even the reinvigorated Putin government. Offering to a selected group of Russian bankers the perspective of conducting profitable business in a temporarily concentrated market, can help overcome resistance; similarly, a policy of favoring solvent banks in

\footnotetext{
${ }^{21}$ L. Radecki, "Banks' Payment Driven Revenues", Economic Policy Review, Vol. 5 no. 2, Federal Reserve Bank of New York, 1999

22 Perotti and Suarez (1999); Caminal and Matutes (1997); Hellman Murdock and Stiglitz (1998)
} 
takeovers of banks in trouble, may support tighter enforcement. As in all such "grand schemes" in Russia, however, the key is that the rules of this game need to be guarded by a responsible central government rather than being privatized.

An additional advantage of the proposed system is that it would help create a stable base for financing the government deficit, without relying again on arrears and monetization. The use of the deposit base would reduce the reliance of state funding on speculative institutions and inflows of short-term capital from abroad. The experience of Latin America suggests that it is even possible to reverse capital flight once stability is established in the government debt market, and that this policy has to start with domestically held (but currently not intermediated) savings. Russia needs to start precisely at this point.

Once interest rates decline as a result of domestic debt stabilization, and significant improvements are achieved in the protection of creditor rights, lending to the real sector can commence on a large scale without jeopardizing the safety of the funds deposited. Any earlier attempt is doomed to failure.

Our proposal relies on solvency of the government debt. Clearly, an efficient banking sector can only be created in an environment of fiscal stabilization. At the same time, the narrow banking proposal offers an important avenue for creating a safer domestic government bond market which would lead towards greater fiscal stability.

\section{Conclusions}

This paper has attempted to describe the hidden dynamics of the Russian banking crisis, , and to offer a minimalist restructuring strategy based on a deeply cynical reading of the current Russian context. It has outlined the institutional structure which produced extreme incentives to strip and export cash, leaving the banking sector in shatters. Our conclusion is that while success for Central European businessmen reflected their capacity to strive in open competition, in Russia it has been the result of their capacity to capture resources flowing out of the State or to seize oligopolistic or protectionist rents (see also Johnson, Macmillan and Woodruff, 1998).

How can we compare this response to the case of other transition countries where stabilization succeeded, such as in Central Europe ? Clearly, the level and distribution of restructuring costs in the economy matters for the individual decisions as well as for the collective outcome. The existence of a sufficiently strong presocialism legal tradition may have helped other countries to build credibility around the new legal and regulatory framework. In the end, enforcement is in fact endogenous; only when enough citizens choose to 
obey the law, it becomes possible to enforce it on the few who do not comply. Figure 10 confirms the relative standing of Russia and other FSU countries in terms of institutional capacity for legal enforcement. Other reasons should be sought in the perceived ability of the political system to commit to continued reforms and strengthening of the rule of law. Possibly the single most important factor determining commitment ability was the prospect of joining the European Union, an objective shared by the overwhelming majority of the population in most Central and Eastern European countries, including the Baltic states. Unfortunately, this option was not open to Russia.

An important conclusion we draw is that while much can be learned from the Russian crisis experience, to understand the Russian crisis does not require a special methodology of analysis relative to other developing country crises; in other words, the Russian crisis is extraordinary because of its size, not because of its nature. In our opinion and experience, Russia is indeed a special country, because of its size, complexity, and history; and yet Russia is not unique, nor do its citizens have a different system of economic aspirations. Quite simply, the Russian crisis is a large-scale example of the systemic consequences of a structure of perverse individual incentives built on an extremely weak legal environment. While lack of experience, insider resistance, and external factors (the oil price drop, the Asian crisis) all played a role, the insolvency of the Russian State and the deliberate hollowing of all other borrowers were the result of poor incentives, which are both the cause and the self-reinforced result of the failure to establish financial and contractual discipline in the country. Yet Russia is different in one respect: because of its political and military importance, the scale of its financial crisis was made all the more dramatic by the scale of support granted by international institutions to a government leading an unsustainable course of policy, which encouraged capital flight and theft on an unique scale.

It is possible to propose a new reform strategy for Russia only after first having learnt from the mistakes of the past. In a context where enforcement is weak or non credible, all economic agents come to expect widespread noncompliance, which weakens any opportunity to supervise and enforce. In such cases, cynical expectations become self-fulfilling. Any regulatory strategy which focuses on prudential regulation will fail in the same circumstances as private contract enforcement. The sole remaining strategy is to identify market structures and regulatory incentives which can affect individual incentives for banking solvency. As it has been the case in Western countries at their early stage of financial development, crude restrictions, limited entry and market segmentation are needed to control opportunistic behavior which can escape a more liberal, rule-based regulatory policy.

These lessons for banking reform may therefore apply broadly to countries whose legal and governance circumstances are comparable to Russia. The frequent failure of reform attempts has been in part the result 
of an excessive use of aggregate tools such as monetary stabilization and conventional bank supervisory rules, which fail to provide direct incentives and may be reversed by collective noncompliance behavior.

\section{BIBLIOGRAPHY}

Berglof E., Roland G. (1998), "Soft Budget Constraints and Banking in Transition Economies", Journal of Comparative Economics, Vol. 26, $\mathrm{n}^{\circ} 1$ : 18-40.

Bernard Black, Reinier Kraakman \& Anna Tarassova, Russian Privatization and Corporate Governance: What Went Wrong?, 52 Stanford Law Review 1731-1808 (2000)

Carlin W., Fries S., Schaffer M., Seabright P. (2000), "Barter and non-monetary transactions in transition economies : Evidence from a cross-country survey", EBRD Working Paper 50, London

Commander S., Mummsen C. (1998), "Different types of non-monetary Transactions in Russia", EBRD, Working Paper 37 , December

Corsetti, Giancarlo, Paolo Pesenti and Nouriel Roubini, "What Caused the Asian Currency and Financial Crisis ?", mimeo, Yale University, 1998

Corsetti, Giancarlo, Paolo Pesenti and Nouriel Roubini, "Paper Tigers? A Model of the Asian Crisis", European Economic Review, 1999

Earle J.S., Estrin S., Leshenko L. (1996), "Privatization versus Competition: Changing Behavior for Russian Enterprises'", CEPR Working Paper, ${ }^{\circ} 136$.

Fries, Steven, Damien Neven, Charles Ng and Paul Seabright (1998), "The Performance of the Banking System in Transition", EBRD working paper

Gaddy, Clifford, Ickes Barry (1998), "Russia’s virtual economy”, Foreign Affairs, 77, September October.

Gelfer S, Pistor K. and Raiser M. (2000), "Law and Finance in Transition Economies", EBRD working paper no. 48, London

Gelfer S and E Perotti (2001), Red Barons or Robber Barons ? Investment Financing in Russian FIGs", forthcoming, European Economic Review

Glaeser, Edward and Andrei Shleifer, "A Case for Quantity Regulation", Harvard Institute of Economic Research Paper No. 1909, January 2001

Ivanova Natasha, Charles Wyplosz (1999), "Arrears: the Tide that is Drowning Russia", RECEP mimeo, Moscow

Johnson S., McMillan J., Woodruff C. (1999), "Contract enforcement in transition", EBRD Working Paper 45, London

Kaufmann D., A. Kraay and P. Zoido Lobaton (1999b), “Aggregating Governance Indicators", mimeo, The World Bank.

Krugman, P. (1998), "What Happened to Asia?" January 1998. Http://web.mit.edu/krugman/www/DISINTER.html Marin, Dalia and Monika Schnitzer, (1999), "Disorganization and Financial Collapse”, CEPR discussion paper no 2245, London 
Marin M., Schnitzer M. (2000), Contracts in Trade and Transition: The Fall and Rise of Barter, Cambridge, forthcoming, MIT Press

Mitchell, Janet, 1998. "Strategic Creditor Passivity, Regulation and Bank Bailouts", CEPR Discussion Paper no. 1780, London

Modigliani, Franco and Enrico Perotti, "Security Markets versus Bank Finance: Legal Enforcement and Investor Protection", International Review of Finance, 2000

Nadezhda Ivanova and Charles Wyplosz, "Who Lost Russia?", working paper, Graduate Institute of International Studies, Universite' de Geneve, February 2001

OECD (2000), Economic Survey, Russia, Paris, OECD, march.

Perotti, Enrico and Stanislaw Gelfer, "Red Baron or Robber Barons ?", European Economic Review, forthcoming, 2001

Perotti, Enrico and Jerome Sgard, "The Russian Meltdown", University of Amsterdam mimeo, 2000

Perotti, Enrico, "A medium term strategy for bank restructuring in Russia", RECEP policy memo, 1998

Perotti, Enrico and Javier Suarez "Preemptive Policy for Systemic Banking Crises", mimeo, University of Amsterdam, 2000

Perotti, Enrico "Inertial Credit and Opportunistic Arrears in Transition", European Economic Review, Vol. 42 (1998), pp. 1703-1725

Pistor, Katharina (2000) "Patterns of legal change: shareholder and creditor rights in transition economies", EBRD Working Paper, 49, London

Popov, Vladimir, "Currency Crisis in Russia in a Wider Context", mimeo, 2000

Radecki, L. "Banks' Payment Driven Revenues", Economic Policy Review, Vol. 5 no. 2, Federal Reserve Bank of New York, 1999

Radelet, Steven and Jeffrey Sachs, 1998, "The Onset of the East Asian financial crisis, NBER working paper 6580, August, Cambridge, Massachusetts

Roland, Gerard and Thierry Verdier, 1994, Privatization in Eastern Europe: irreversibility and critical mass effects, Journal of Public Economics, 161-183.

Sgard, Jerome (1997), Europe de l'Est, la transition économique, Paris, Flammarion.

Shleifer, Andrei and D. Treisman, "Without a Map: Political Tactics and Economic Reform in Russia", MIT Press, 1999, Cambridge, MA

Tang, Helena, Edda Zoli and Irina Klytchnikova, "Resolving Banking Crises in Transition Countries: Fiscal Costs and Related Issues", World Bank mimeo, Washington, 2000

Westin, P. (2000), "Export revenues: repatriation or expropriation", Russian Economic Trends, February, pp. 3-10. 
Figure 1. Effective exchange rates (January $1997=100$ )

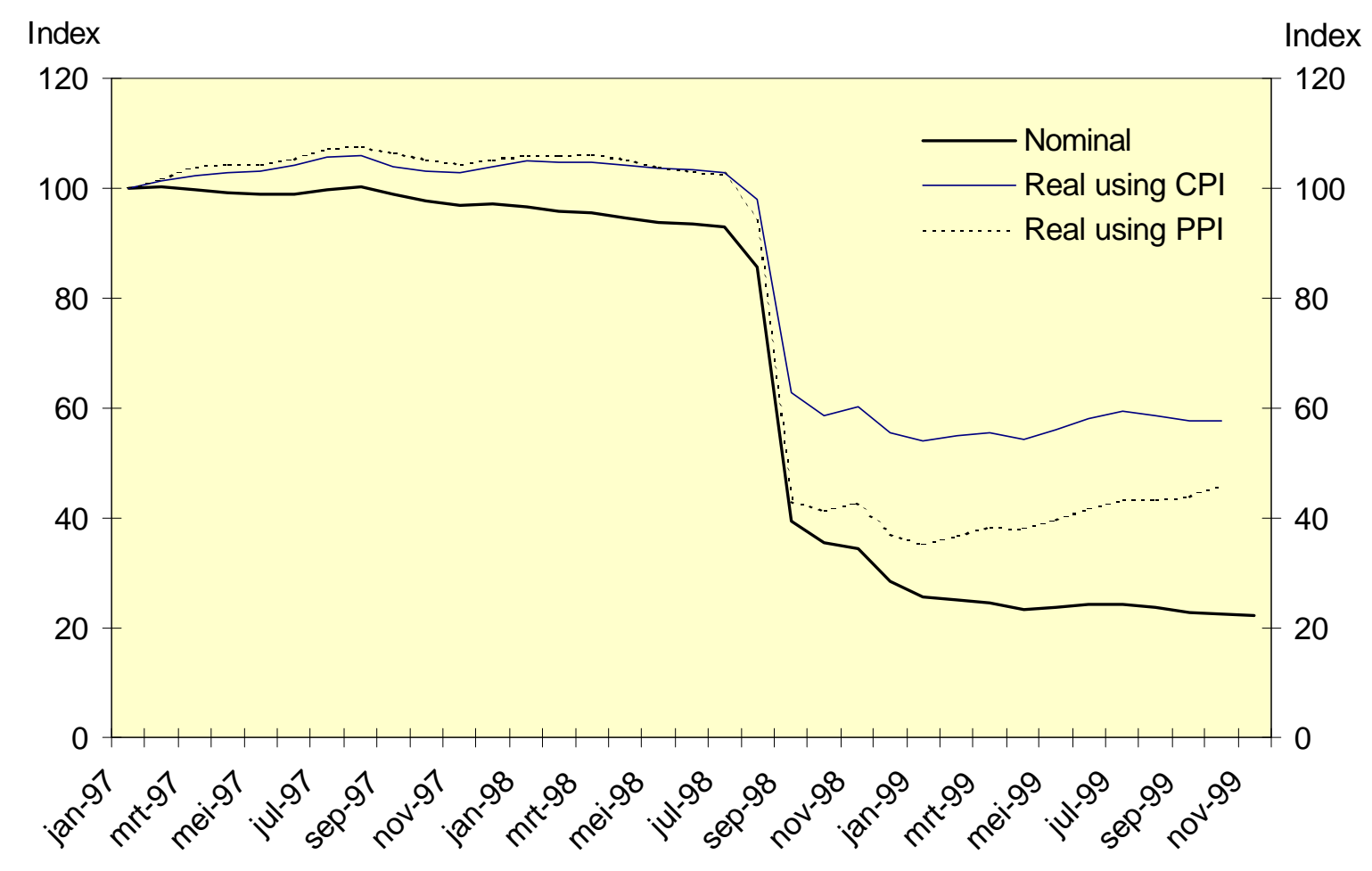




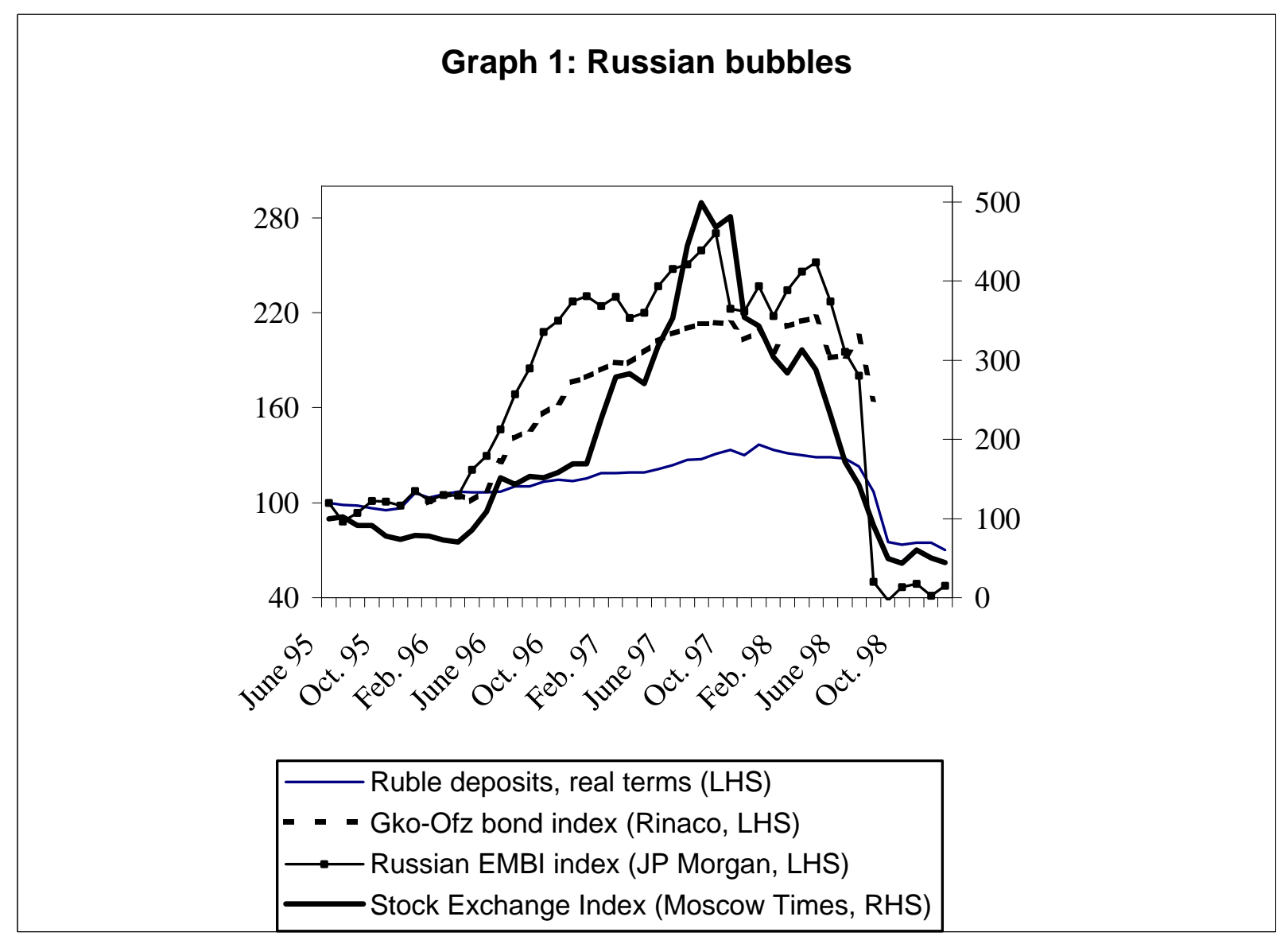


Figure 2: Estimated capital flight from Russia

Source: elaboration on data from Russian Economic Trends, 2000

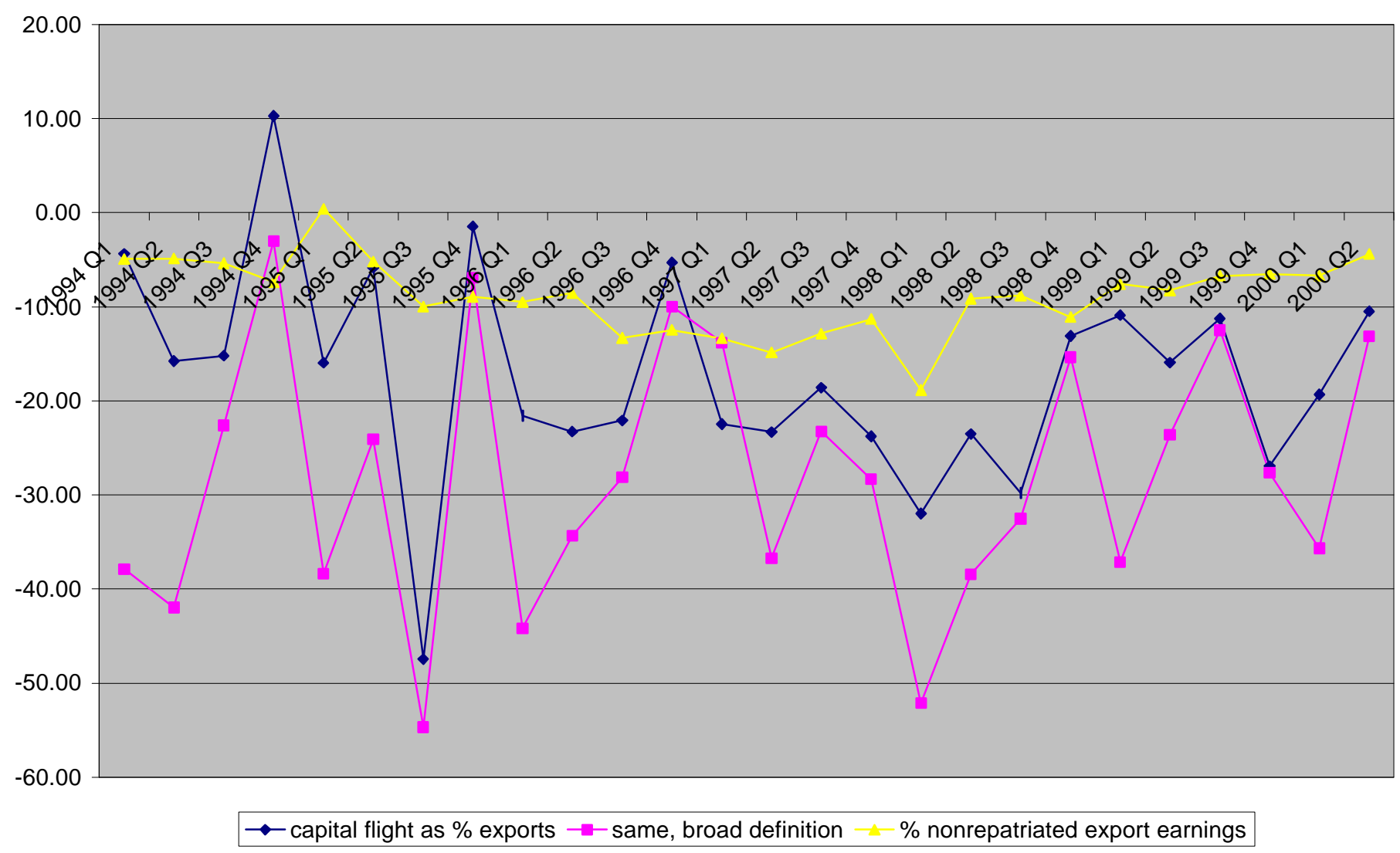


Figure 3. Enterprise arrears as a percentage of GDP Source: OECD

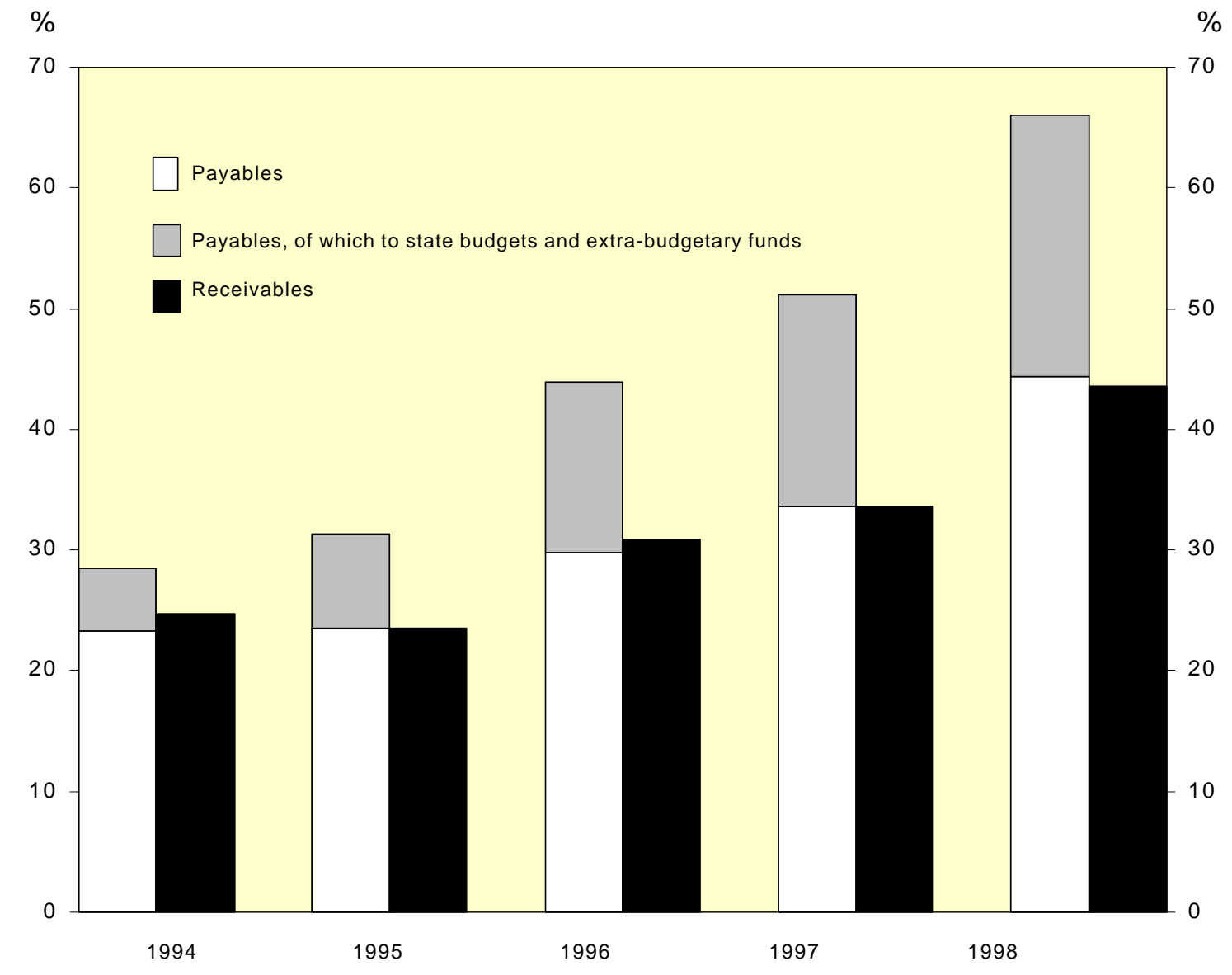


Figure 4. Wage arrears

(December $1997=100$ )

Source: OECD

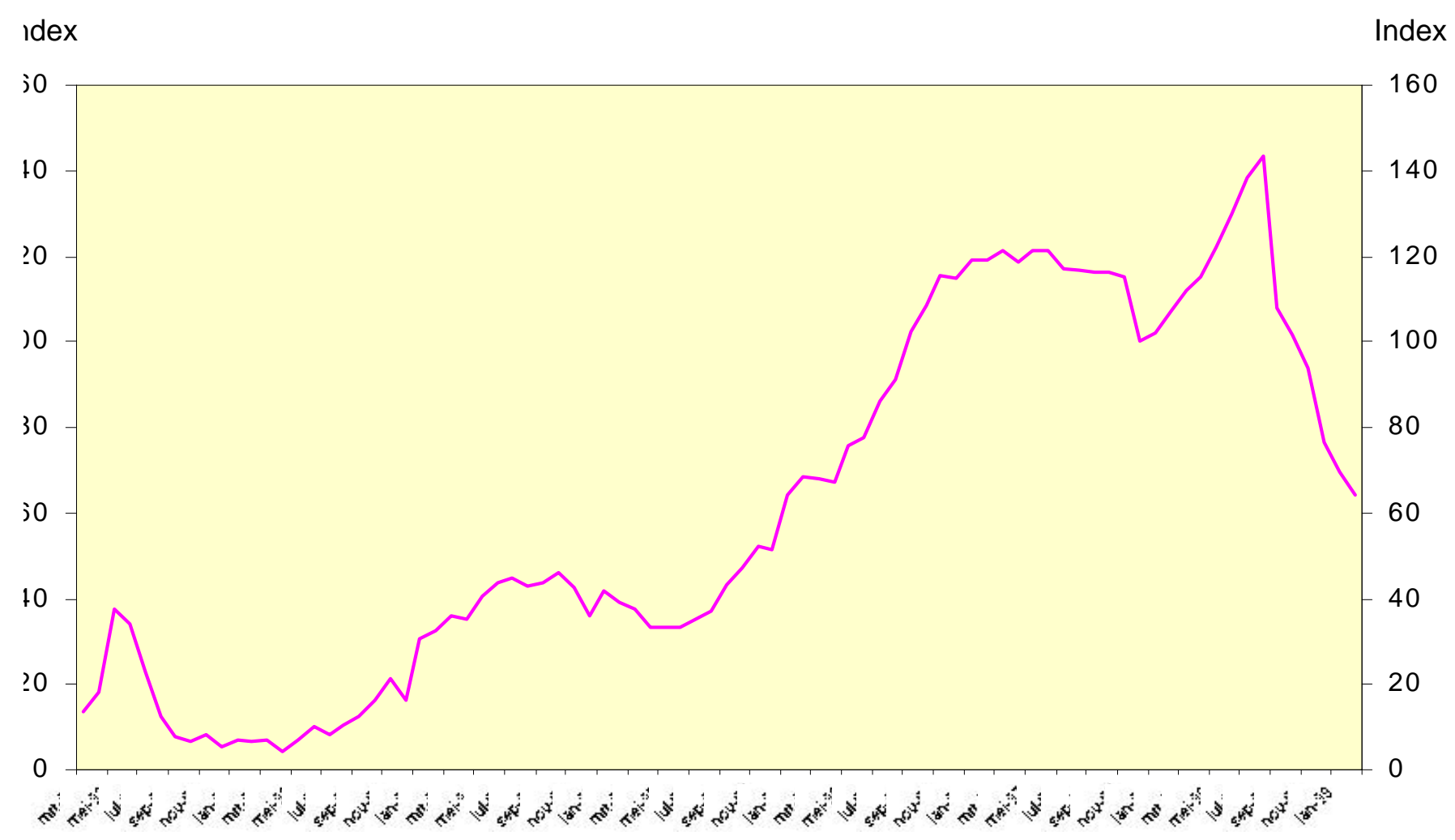


Figure 5: Tax revenues and tax offsets

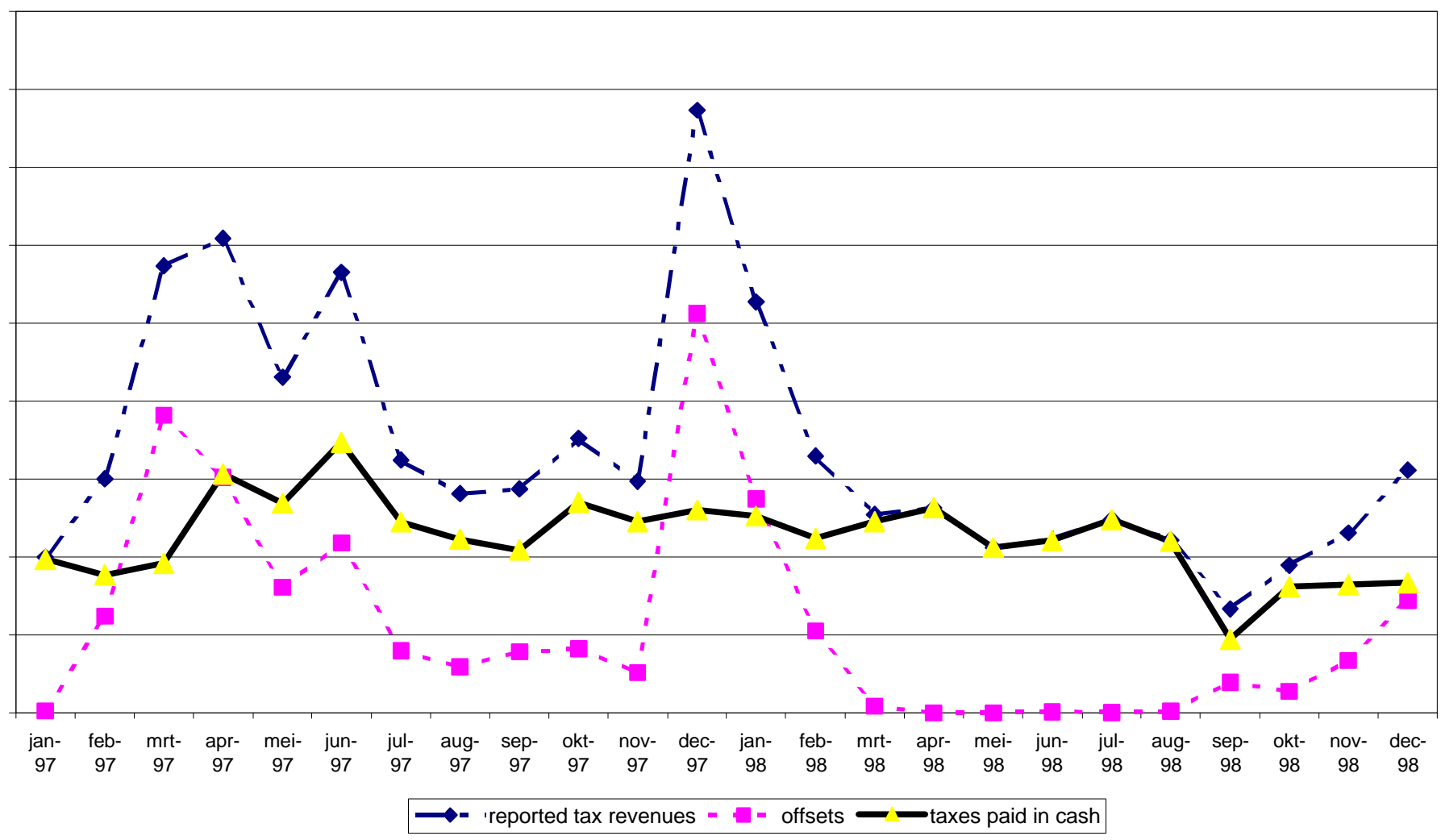


Figure 6. The share of non-cash receipts for industrial firms

(Source: OECD)

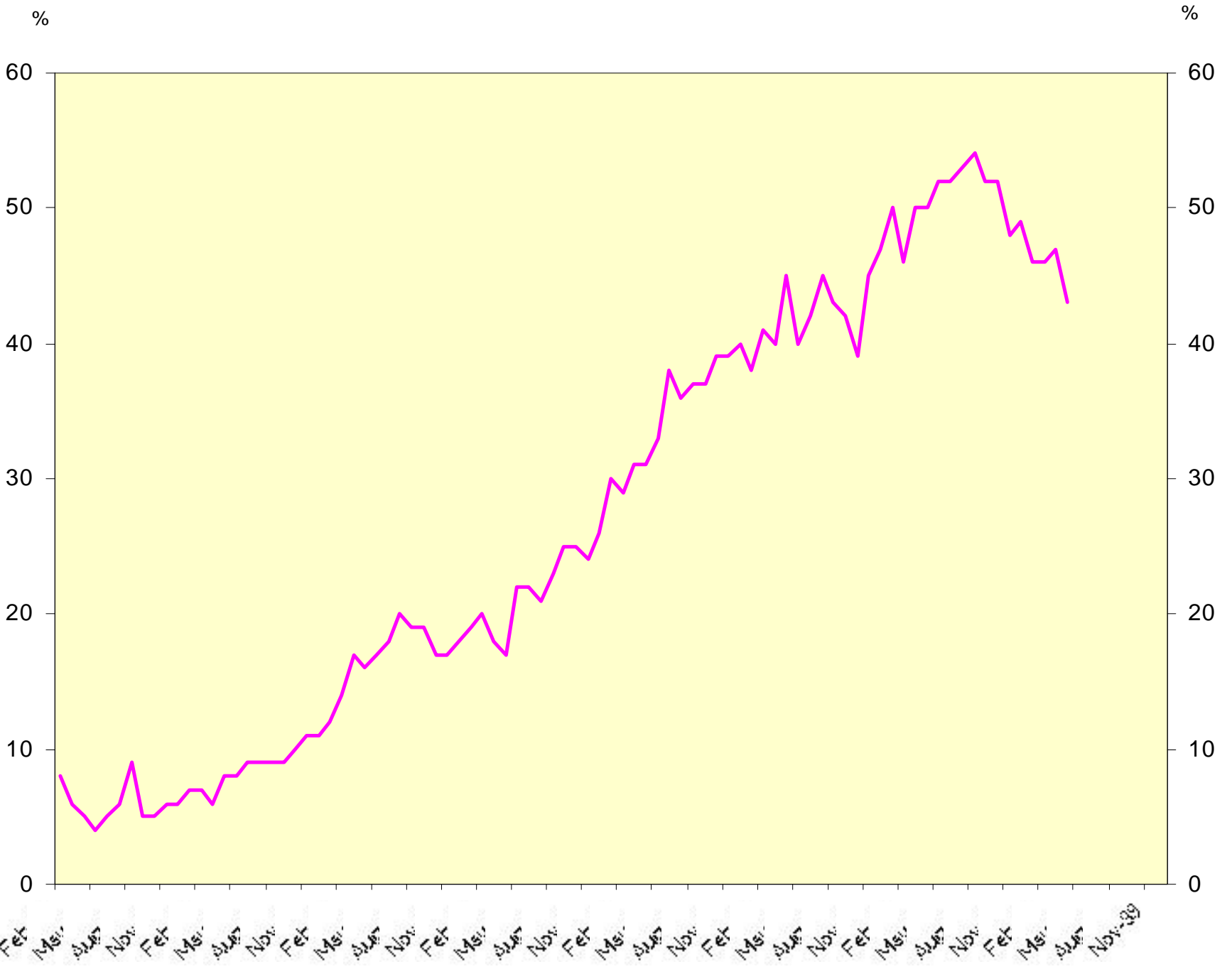


igure 7. Commercial credit to the non-financial sector, ion-cash transactions and average returns on GKOs

Source: OECD)

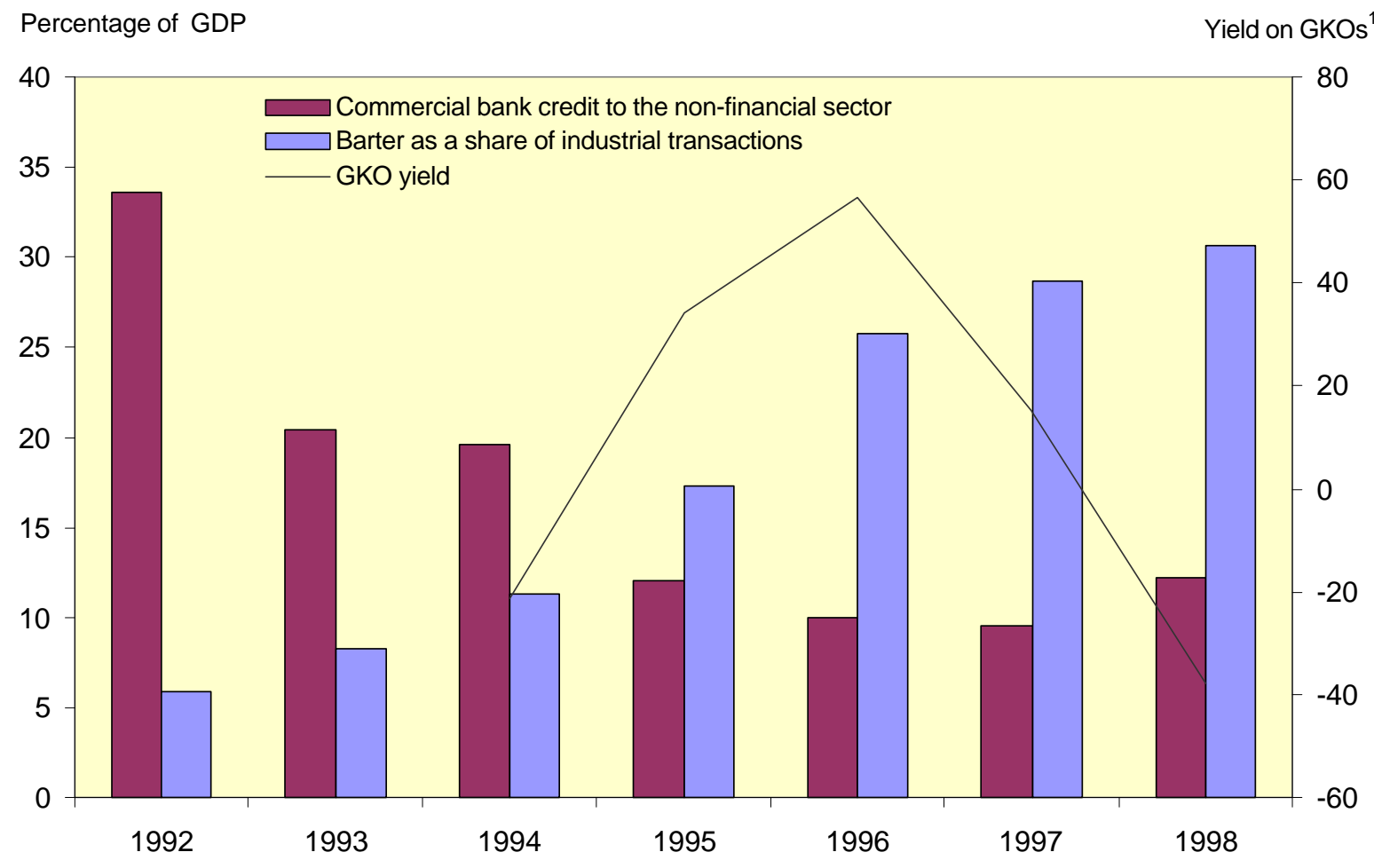


Figure 8. Open foreign position and government bond holdings of Russian commercial banks

Source: OECD

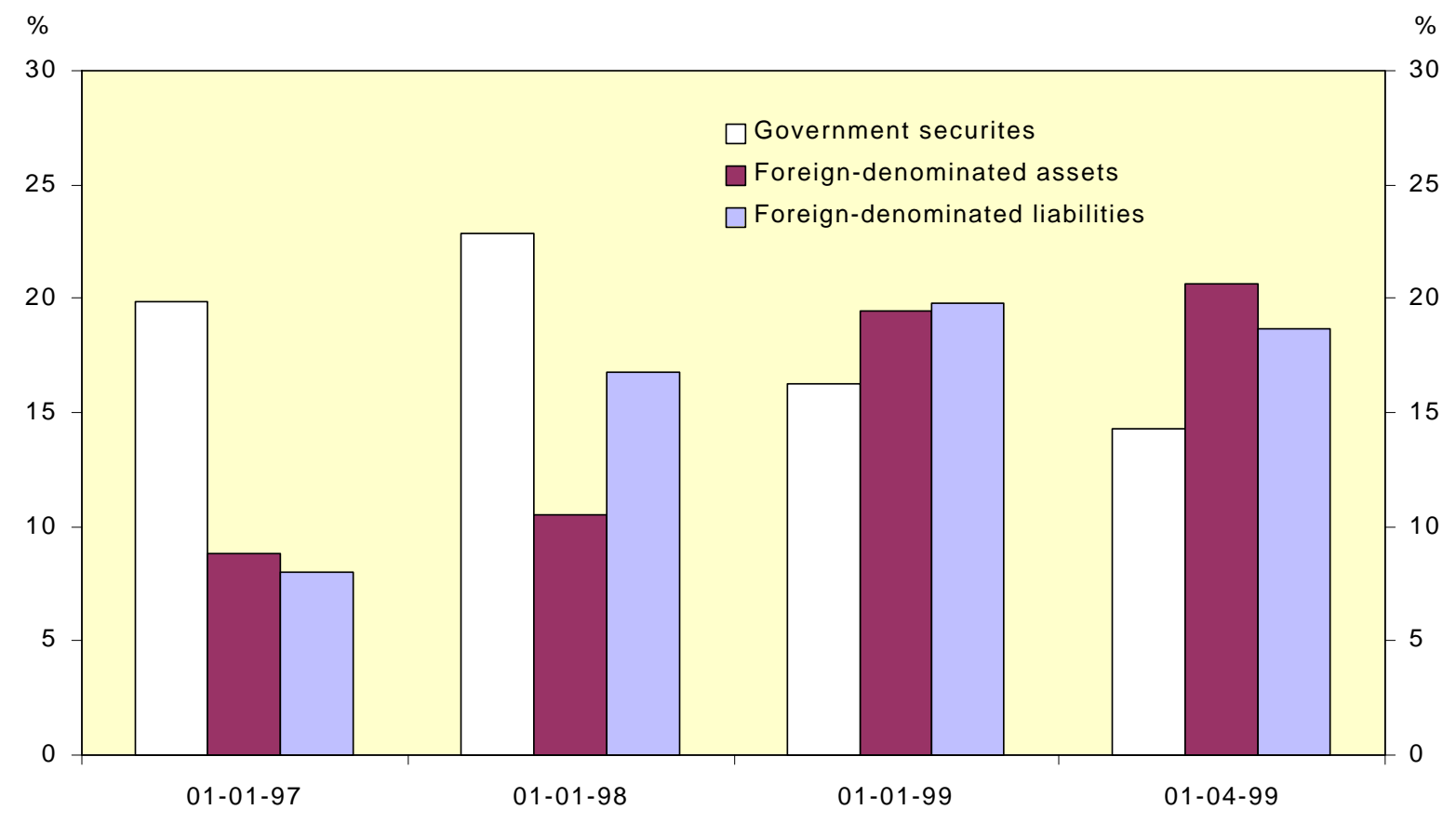


Table I Number of bank licences withdrawn for violating laws or CBR rules

\begin{tabular}{lr} 
II-96 & 27 \\
II-96 & 114 \\
III-96 & 64 \\
IV-96 & 61 \\
I-97 & 93 \\
II-97 & 93 \\
III-97 & 93 \\
IV-97 & 75 \\
I-98 & 58 \\
II-98 & 60 \\
III-98 & 62 \\
IV-98 & 42 \\
I-99 & 69 \\
II-99 & 52 \\
III-99 & 54 \\
IV-99 & 44 \\
I-00 & 30 \\
II-00 & 22 \\
III-00 & 30 \\
IV-00 & 14 \\
\hline
\end{tabular}

$\begin{array}{lr}\text { Total } & 969\end{array}$ 
Figure 9 : Bank deposits, in real term (Source: Perotti and Sgard, 2000)

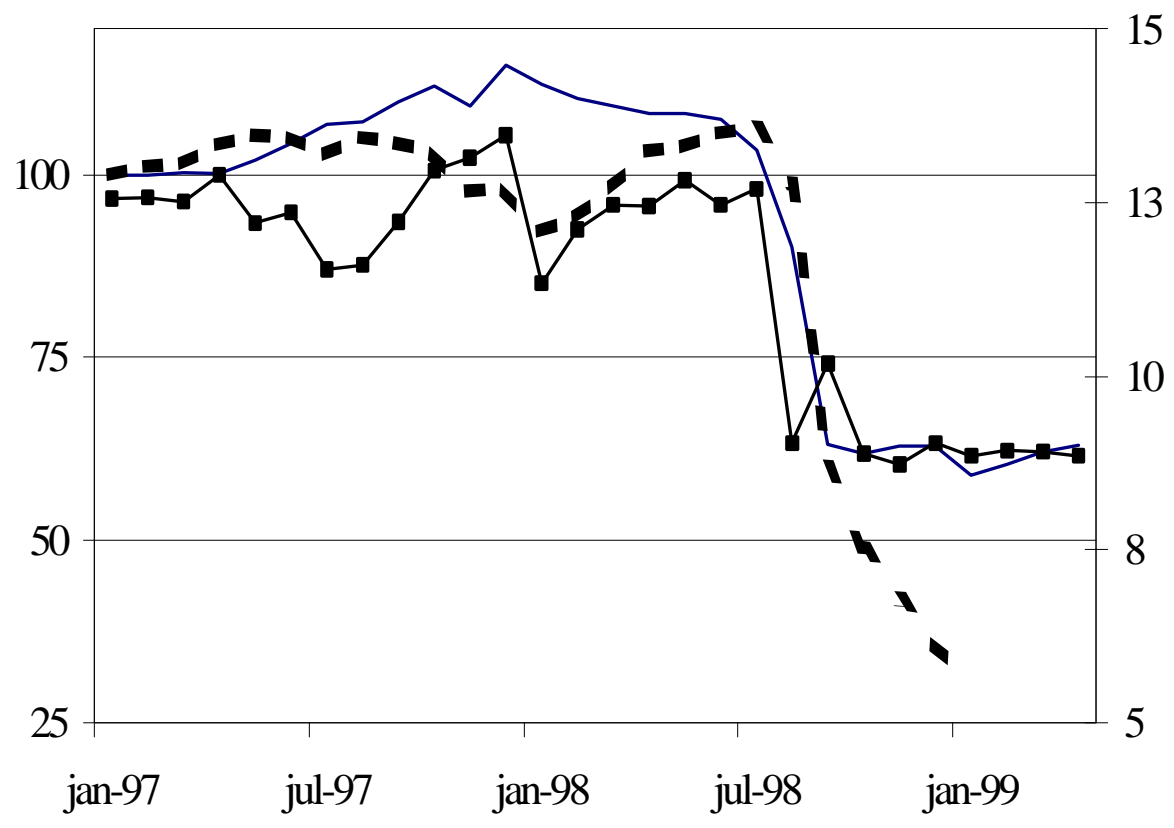


Figure 10

Overall Average Institutional Quality (1997):

Deviation of national index from the average for Industrialized Countries

Source: Kaufmann et al. (1999b)

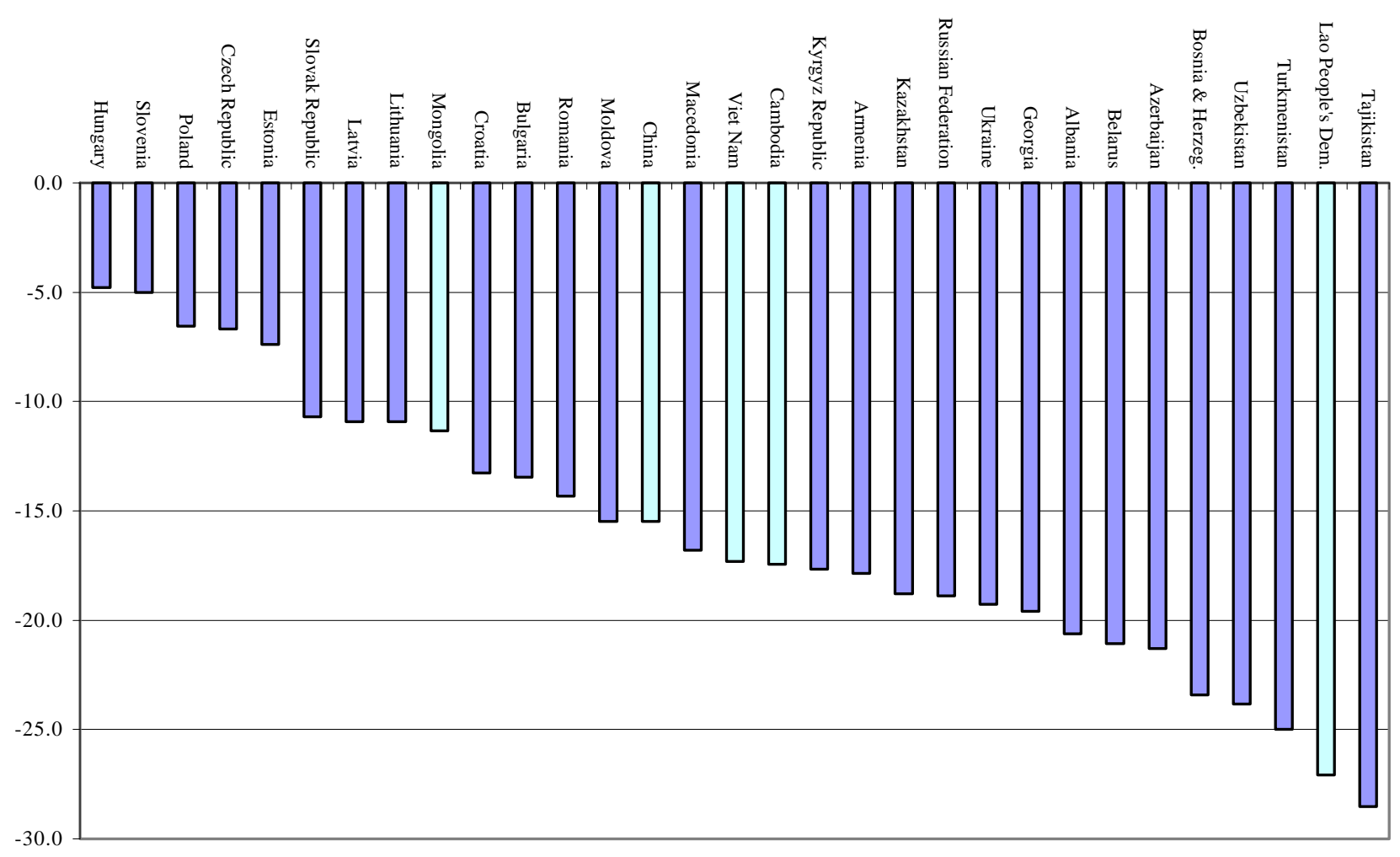


Table 2

Russian banks with the largest forward contracts on July 1, 1998 (R bn)

\begin{tabular}{|lcc|}
\hline & Forward & As \% of assets \\
Contracts & \\
Inkombank & 169.2 & 469.9 \\
National Reserve & 99.4 & 944.4 \\
MDM-Bank & 84.6 & 4656.8 \\
Unibest & 77.6 & 3709.2 \\
Tokobank & 66.9 & 871.7 \\
ONEKSIM-bank & 47.3 & 197.9 \\
Sberbank & 39.5 & 19.7 \\
SBS-Agro & 31.2 & 115.8 \\
Avtobank & 26.8 & 303.2 \\
Gazprombank & 25.7 & 189.5 \\
Menatep & 24.2 & 131.5 \\
Vneshtorgbank & 24.1 & 132.9 \\
Mezhkombank & 23.6 & 690.5 \\
Rossiski Kredit & 22.0 & 113.8 \\
Metkombank & 19.2 & 2000.0 \\
\hline
\end{tabular}

Source: Profile magazine 


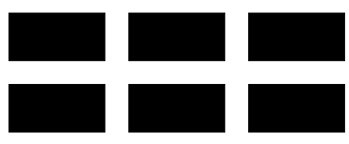

THE WILLIAM DAVIDSON INSTITUTE

AT THE UNIVERSITY OF MICHIGAN BUSINESSSCHOOL

\section{DAVIDSON INSTITUTE WORKING PAPER SERIES - Most Recent Papers}

The entire Working Paper Series is available at: www.wdi.bus.umich.edu

CURRENT AS OF $7 / 05 / 01$

\begin{tabular}{|c|c|c|}
\hline Publication & Authors & Date \\
\hline $\begin{array}{l}\text { No. } 379 \text { Lessons from the Russian Meltdown: The Economics of Soft } \\
\text { Legal Constraints }\end{array}$ & Enrico Perotti & Mar. 2001 \\
\hline No. 378 Effective Tax Rates in Transition & Vlad Ivanenko & May 2001 \\
\hline $\begin{array}{l}\text { No. } 377 \text { Some Explanations for Changes in the Distribution of } \\
\text { Household Income in Slovakia: } 1988 \text { and } 1996\end{array}$ & $\begin{array}{l}\text { Thesia Garner and Katherine } \\
\text { Terrell }\end{array}$ & May 2001 \\
\hline $\begin{array}{l}\text { No. } 376 \text { Competition and Enterprise Performance in Transition } \\
\text { Economies: Evidence from a Cross-country Survey }\end{array}$ & $\begin{array}{l}\text { Wendy Carlin, Steven Fries, } \\
\text { Mark Schaffer and Paul Seabright }\end{array}$ & May 2001 \\
\hline $\begin{array}{l}\text { No. } 375 \text { Why More is Actually Less: New Interpretations of China's } \\
\text { Labor-Intensive FDI }\end{array}$ & Yasheng Huang & May 2001 \\
\hline No. 374 Economic Fragmentation and FDI in China & Yasheng Huang & May 2001 \\
\hline $\begin{array}{l}\text { No. } 373 \text { Earnings Disparities in the Czech Republic: Evidence of the } \\
\text { Past Decade and Cross-National Comparison }\end{array}$ & Jiri Vecernik & May 2001 \\
\hline $\begin{array}{l}\text { No. } 372 \text { Economic Reform, Democracy and Growth During Post- } \\
\text { Communist Transition }\end{array}$ & Jan Fidrmuc & Mar. 2001 \\
\hline $\begin{array}{l}\text { No. } 371 \text { Do Multinational Enterprises Substitute Parent Jobs for Foreign } \\
\text { Ones? Evidence from Firm Level Panel Data }\end{array}$ & Jozef Konings and Alan Murphye & Apr. 2001 \\
\hline $\begin{array}{l}\text { No. } 370 \text { From Needs to the Market: Changing Inequality of Household } \\
\text { Income in the Czech Transition }\end{array}$ & Jiri Vecernik & Apr. 2001 \\
\hline $\begin{array}{l}\text { No. } 369 \text { Competition and Corporate Governance: Substitutes or } \\
\text { Complements? Evidence from the Warsaw Stock Exchange }\end{array}$ & $\begin{array}{l}\text { Irena Grosfeld and Thierry } \\
\text { Tressel }\end{array}$ & Mar. 2001 \\
\hline $\begin{array}{l}\text { No. } 368 \text { Multinational Corporations as Catalyst for Industrial } \\
\text { Development: The Case of Poland }\end{array}$ & $\begin{array}{l}\text { Carlo Altomonte and Laura } \\
\text { Resmini }\end{array}$ & Feb. 2001 \\
\hline No. 367 A Multi-Task Theory of the State Enterprise Reform & $\begin{array}{l}\text { Chong-En Bai, David D. Li, } \\
\text { Zhigang Tao, and Yijiang Wang }\end{array}$ & Mar. 2001 \\
\hline No. 366a Confidence Building in Emerging Stock Markets & Enrico C. Perotti and Luc Laeven & June 2001 \\
\hline No. 366 Confidence Building in Emerging Stock Markets & $\begin{array}{l}\text { Enrico C. Perotti, Luc Laeven, } \\
\text { and Pieter van Oijen }\end{array}$ & Dec. 2000 \\
\hline $\begin{array}{l}\text { No. } 365 \text { Incentive Contracting versus Ownership Reforms: Evidence } \\
\text { from China's Township and Village Enterprises }\end{array}$ & $\begin{array}{l}\text { Chun Chang, Brian McCall, and } \\
\text { Yijang Wang }\end{array}$ & Nov. 2000 \\
\hline $\begin{array}{l}\text { No. } 364 \text { Individual Pay and Outside Options: Evidence from the Polish } \\
\text { Labour Force Survey }\end{array}$ & $\begin{array}{l}\text { Fiona Duffy and Patrick Paul } \\
\text { Walsh }\end{array}$ & Mar. 2001 \\
\hline $\begin{array}{l}\text { No. } 363 \text { Investment, Credit Rationing and the Soft Budget Constraint: } \\
\text { Evidence from Czech Panel Data (revised Davidson Institute Working } \\
\text { Paper No. 60a) }\end{array}$ & Lubomír Lízal and Jan Svejnar & Feb. 2001 \\
\hline $\begin{array}{l}\text { No. } 362 \text { A Network Perspective on Inter-Organizational Transfer of } \\
\text { R\&D Capabilities: A Study of International Joint Ventures in Chinese } \\
\text { Automobile Industry }\end{array}$ & $\begin{array}{l}\text { Zheng Zhao, Jaideep Anand and } \\
\text { Will Mitchell }\end{array}$ & Feb. 2001 \\
\hline $\begin{array}{l}\text { No. } 361 \text { Network Restructuring and Firm Creation in East-Central } \\
\text { Europe: A Public-Private Venture }\end{array}$ & Gerald A. McDermott & Dec. 2000 \\
\hline $\begin{array}{l}\text { No. } 360 \text { Responses of Private and Public Schools to Voucher Funding: } \\
\text { The Czech and Hungarian Experience }\end{array}$ & $\begin{array}{l}\text { Randall K. Filer and Daniel } \\
\text { Münich }\end{array}$ & Oct. 2000 \\
\hline $\begin{array}{l}\text { No. } 359 \text { Labor Market Uncertainty and Private Sector Labor Supply in } \\
\text { Russia }\end{array}$ & Steven Stillman & Sept. 2000 \\
\hline $\begin{array}{l}\text { No. } 358 \text { Russian Roulette-Expenditure Inequality and Instability in } \\
\text { Russia, 1994-1998 }\end{array}$ & Branko Jovanovic & Sept. 2000 \\
\hline No. 357 Dealing with the Bad Loans of the Chinese Banks & John P. Bonin and Yiping Huang & Jan. 2001 \\
\hline
\end{tabular}


No. 356 Retail Banking in Hungary: A Foreign Affair?

No. 355 Optimal Speed of Transition: Micro Evidence from the Czech Republic

No. 354 Political Instability and Growth in Dictatorships

No. 353 Disintegration and Trade

No. 352 Social Capital and Entrepreneurial Performance in Russia: A Panel Study

No. 351 Entrepreneurial Versatility, Resources and Firm Performance in Russia: A Panel Study

No. 350 The Dynamics of Entrepreneurial Networks in a Transitional Economy: The Case of Russia

No. 349a R\&D and Technology Spillovers via FDI: Innovation and Absorptive Capacity

No. 349 R\&D and Technology Spillovers via FDI: Innovation and Absorptive Capacity

No. 348 Microeconomic aspects of Economic Growth in Eastern Europe and the Former Soviet Union, 1950-2000

No. 347 Effective versus Statutory Taxation: Measuring Effective Tax Administration in Transition Economies

No. 346 Objectives and Constraints of Entrepreneurs: Evidence from Small and Medium Size Enterprises in Russia and Bulgaria

No. 345 Corruption and Anticorruption in the Czech Republic

No. 344 The Effects of Direct Foreign Investment on Domestic Firms

No. 343 On the Identification of Relative Wage Rigidity Dynamics

No. 342 The Determinants of Foreign Direct Investment in Transition

Economies

No. 341 The Global Spread of Stock Exchanges, 1980-1998

No. 340 The Costs and Benefits of Euro-isation in Central-Eastern

Europe Before or Instead of EMU Membership

No. 339 Debt Overhang and Barter in Russia

No. 338 Firm Performance and the Political Economy of Corporate Governance: Survey Evidence for Bulgaria, Hungary, Slovakia and Slovenia

No. 337 Investment and Instability

No. 336 The Evolution of the Insurance Sector in Central and

Eastern Europe and the former Soviet Union

No. 335 Institutional Technology and the Chains of Trust: Capital

Markets and Privatization in Russia and the Czech Republic

No. 334 The Evolution of Market Integration in Russia

No. 333 Efficiency and Market Share in Hungarian Corporate Sector No. 332 Search-Money-and-Barter Models of Financial Stabilization

No. 331 Worker Training in a Restructuring Economy: Evidence from the Russian Transition

No. 330 Economic Development in Palanpur 1957-1993: A Sort of Growth

No. 329 Trust, Organizational Controls, Knowledge Acquisition from the Foreign Parents, and Performance in Vietnamese International Joint Ventures

No. 328 Comparative Advertising in the Global Marketplace: The Effects of Cultural Orientation on Communication

\begin{tabular}{|c|c|}
\hline John P. Bonin and István Ábel & Dec. 2000 \\
\hline $\begin{array}{l}\text { Stepan Jurajda and Katherine } \\
\text { Terrell }\end{array}$ & Dec. 2000 \\
\hline $\begin{array}{l}\text { Jody Overland, Kenneth L. } \\
\text { Simons and Michael Spagat }\end{array}$ & Nov. 2000 \\
\hline Jarko Fidrmuc and Jan Fidrmuc & Nov. 2000 \\
\hline Bat Batjargal & Dec. 2000 \\
\hline Bat Batjargal & Dec. 2000 \\
\hline Bat Batjargal & Dec. 2000 \\
\hline Yuko Kinoshita & Apr. 2001 \\
\hline Yuko Kinoshita & Nov. 2000 \\
\hline Sergei Guriev and Barry W. Ickes & Nov. 2000 \\
\hline $\begin{array}{l}\text { Mark E. Schaffer and Gerard } \\
\text { Turley }\end{array}$ & Nov. 2000 \\
\hline $\begin{array}{l}\text { Francesca Pissarides, Miroslav } \\
\text { Singer and Jan Svejnar }\end{array}$ & Oct. 2000 \\
\hline $\begin{array}{l}\text { Lubomír Lízal and Evžen } \\
\text { Kočenda }\end{array}$ & Oct. 2000 \\
\hline Jozef Konings & Oct. 2000 \\
\hline Patrick A. Puhani & Oct. 2000 \\
\hline Alan A. Bevan and Saul Estrin & Oct. 2000 \\
\hline Klaus Weber and Gerald F. Davis & Nov. 2000 \\
\hline D. Mario Nuti & Oct. 2000 \\
\hline $\begin{array}{l}\text { Sergei Guriev, Igor Makarov and } \\
\text { Mathilde Maurel }\end{array}$ & Sept. 2000 \\
\hline $\begin{array}{l}\text { Patrick Paul Walsh and Ciara } \\
\text { Whela }\end{array}$ & July 2000 \\
\hline $\begin{array}{l}\text { Nauro F. Campos and Jeffrey B. } \\
\text { Nugent }\end{array}$ & May 2000 \\
\hline Robert B.K. Pye & Aug. 2000 \\
\hline Bruce Kogut and Andrew Spicer & Aug. 2000 \\
\hline $\begin{array}{l}\text { Daniel Berkowitz and David N. } \\
\text { DeJong }\end{array}$ & Aug. 2000 \\
\hline László Halpern and Gábor Körösi & July 2000 \\
\hline $\begin{array}{l}\text { S.I. Boyarchenko and S.Z. } \\
\text { Levendorskii }\end{array}$ & July 2000 \\
\hline $\begin{array}{l}\text { Mark C. Berger, John S. Earle } \\
\text { and Klara Z. Sabirianova }\end{array}$ & Aug. 2000 \\
\hline Peter Lanjouw & Aug. 2000 \\
\hline $\begin{array}{l}\text { Marjorie A. Lyles, Le Dang } \\
\text { Doanh, and Jeffrey Q. Barden }\end{array}$ & June 2000 \\
\hline $\begin{array}{l}\text { Zeynep Gürhan-Canli and } \\
\text { Durairaj Maheswaran }\end{array}$ & Aug. 2000 \\
\hline
\end{tabular}




\begin{tabular}{|c|c|c|}
\hline No. 327 Post Privatization Enterprise Restructuring & Morris Bornstein & July 2000 \\
\hline No. 326 Who is Afraid of Political Instability? & $\begin{array}{l}\text { Nauro F. Campos and Jeffrey B. } \\
\text { Nugent }\end{array}$ & July 2000 \\
\hline No. 325 Business Groups, the Financial Market and Modernization & Raja Kali & June 2000 \\
\hline $\begin{array}{l}\text { No. } 324 \text { Restructuring with What Success? A Case Study of Russian } \\
\text { Firms }\end{array}$ & Susan Linz & July 2000 \\
\hline $\begin{array}{l}\text { No. } 323 \text { Priorities and Sequencing in Privatization: Theory and } \\
\text { Evidence from the Czech Republic }\end{array}$ & $\begin{array}{l}\text { Nandini Gupta, John C. Ham and } \\
\text { Jan Svejnar }\end{array}$ & May 2000 \\
\hline $\begin{array}{l}\text { No. } 322 \text { Liquidity, Volatility, and Equity Trading Costs Across } \\
\text { Countries and Over Time }\end{array}$ & $\begin{array}{l}\text { Ian Domowitz, Jack Glen and } \\
\text { Ananth Madhavan }\end{array}$ & Mar. 2000 \\
\hline $\begin{array}{l}\text { No. } 321 \text { Equilibrium Wage Arrears: A Theoretical and Empirical } \\
\text { Analysis of Institutional Lock-In }\end{array}$ & $\begin{array}{l}\text { John S. Earle and Klara Z. } \\
\text { Sabirianova }\end{array}$ & Oct. 2000 \\
\hline No. 320 Rethinking Marketing Programs for Emerging Markets & $\begin{array}{l}\text { Niraj Dawar and Amitava } \\
\text { Chattopadhyay }\end{array}$ & June 2000 \\
\hline $\begin{array}{l}\text { No. } 319 \text { Public Finance and Low Equilibria in Transition Economies: } \\
\text { the Role of Institutions }\end{array}$ & $\begin{array}{l}\text { Daniel Daianu and Radu } \\
\text { Vranceanu }\end{array}$ & June 2000 \\
\hline $\begin{array}{l}\text { No. } 318 \text { Some Econometric Evidence on the Effectiveness of Active } \\
\text { Labour Market Programmes in East Germany }\end{array}$ & $\begin{array}{l}\text { Martin Eichler and Michael } \\
\text { Lechner }\end{array}$ & June 2000 \\
\hline No. 317 A Model of Russia's "Virtual Economy" & R.E Ericson and B.W Ickes & May 2000 \\
\hline $\begin{array}{l}\text { No. } 316 \text { Financial Institutions, Financial Contagion, and Financial } \\
\text { Crises }\end{array}$ & $\begin{array}{l}\text { Haizhou Huang and Chenggang } \\
\mathrm{Xu}\end{array}$ & Mar. 2000 \\
\hline $\begin{array}{l}\text { No. } 315 \text { Privatization versus Regulation in Developing Economies: The } \\
\text { Case of West African Banks }\end{array}$ & $\begin{array}{l}\text { Jean Paul Azam, Bruno Biais, and } \\
\text { Magueye Dia }\end{array}$ & Feb. 2000 \\
\hline $\begin{array}{l}\text { No. } 314 \text { Is Life More Risky in the Open? Household Risk-Coping and } \\
\text { the Opening of China's Labor Markets }\end{array}$ & John Giles & Apr. 2000 \\
\hline $\begin{array}{l}\text { No. } 313 \text { Networks, Migration and Investment: Insiders and Outsiders in } \\
\text { Tirupur's Production Cluster }\end{array}$ & $\begin{array}{l}\text { Abhijit Banerjee and Kaivan } \\
\text { Munshi }\end{array}$ & Mar. 2000 \\
\hline $\begin{array}{l}\text { No. } 312 \text { Computational Analysis of the Impact on India of the Uruguay } \\
\text { Round and the Forthcoming WTO Trade Negotiations }\end{array}$ & $\begin{array}{l}\text { Rajesh Chadha, Drusilla K. } \\
\text { Brown, Alan V. Deardorff and } \\
\text { Robert M. Stern }\end{array}$ & Mar. 2000 \\
\hline No. 311 Subsidized Jobs for Unemployed Workers in Slo & Jan. C. van Ours & May 2000 \\
\hline No. 310 Determinants of Managerial Pay in the Czech Republic & $\begin{array}{l}\text { Tor Eriksson, Jaromir Gottvald } \\
\text { and Pavel Mrazek }\end{array}$ & May 2000 \\
\hline $\begin{array}{l}\text { No. } 309 \text { The Great Human Capital Reallocation: An Empirical Analysis } \\
\text { of Occupational Mobility in Transitional Russia }\end{array}$ & Klara Z. Sabirianova & Oct. 2000 \\
\hline No. 308 Economic Development, Legality, and the Transplant Effect & $\begin{array}{l}\text { Daniel Berkowitz, Katharina } \\
\text { Pistor, and Jean-Francois Richard }\end{array}$ & Feb. 2000 \\
\hline $\begin{array}{l}\text { No. } 307 \text { Community Participation, Teacher Effort, and Educational } \\
\text { Outcome: The Case of El Salvador's EDUCO Program }\end{array}$ & Yasuyuki Sawada & Nov. 1999 \\
\hline No. 306 Gender Wage Gap and Segregation in Late Transition & Stepan Jurajda & May 2000 \\
\hline $\begin{array}{l}\text { No. } 305 \text { The Gender Pay Gap in the Transition from Communism: } \\
\text { Some Empirical Evidence }\end{array}$ & Andrew Newell and Barry Reilly & May 2000 \\
\hline No. 304 Post-Unification Wage Growth in East Germany & Jennifer Hunt & Nov. 1998 \\
\hline $\begin{array}{l}\text { No. } 303 \text { How Does Privatization Affect Workers? The Case of the } \\
\text { Russian Mass Privatization Program }\end{array}$ & Elizabeth Brainerd & May 2000 \\
\hline $\begin{array}{l}\text { No. } 302 \text { Liability for Past Environmental Contamination and } \\
\text { Privatization }\end{array}$ & Dietrich Earnhart & Mar. 2000 \\
\hline No. 301 Varieties, Jobs and EU Enlargement & $\begin{array}{l}\text { Tito Boeri and Joaquim Oliveira } \\
\text { Martins }\end{array}$ & May 2000 \\
\hline No. 300 Employer Size Effects in Russia & Todd Idson & Apr. 2000 \\
\hline $\begin{array}{l}\text { No. } 299 \text { Information Complements, Substitutes, and Strategic Product } \\
\text { Design }\end{array}$ & $\begin{array}{l}\text { Geoffrey G. Parker and Marshall } \\
\text { W. Van Alstyne }\end{array}$ & Mar. 2000 \\
\hline $\begin{array}{l}\text { No. } 298 \text { Markets, Human Capital, and Inequality: Evidence from Rural } \\
\text { China }\end{array}$ & $\begin{array}{l}\text { Dwayne Benjamin, Loren Brandt, } \\
\text { Paul Glewwe, and Li Guo }\end{array}$ & May 2000 \\
\hline
\end{tabular}


The entire Working Paper Series is available at: www.wdi.bus.umich.edu

\begin{tabular}{|c|c|c|}
\hline No. 297 Corporate Governance in the Asian Financial Crisis & $\begin{array}{l}\text { Simon Johnson, Peter Boone, } \\
\text { Alasdair Breach, and Eric } \\
\text { Friedman }\end{array}$ & Nov. 1999 \\
\hline No. 296 Competition and Firm Performance: Lessons from Russia & J. David Brown and John S. Earle & Mar. 2000 \\
\hline No. 295 Wage Determination in Russia: An Econometric Investigation & $\begin{array}{l}\text { Peter J. Luke and Mark E. } \\
\text { Schaffer }\end{array}$ & Mar. 2000 \\
\hline $\begin{array}{l}\text { No. 294 Can Banks Promote Enterprise Restructuring?: Evidence From } \\
\text { a Polish Bank’s Experience }\end{array}$ & John P. Bonin and Bozena Leven & Mar. 2000 \\
\hline No. 293 Why do Governments Sell Privatised Companies Abroad? & $\begin{array}{l}\text { Bernardo Bortolotti, Marcella } \\
\text { Fantini and Carlo Scarpa }\end{array}$ & Mar. 2000 \\
\hline $\begin{array}{l}\text { No. } 292 \text { Going Public in Poland: Case-by-Case Privatizations, Mass } \\
\text { Privatization and Private Sector Initial Public Offerings }\end{array}$ & Wolfgang Aussenegg & Dec. 1999 \\
\hline $\begin{array}{l}\text { No. 291a Institutional Technology and the Chains of Trust: Capital } \\
\text { Markets and Privatization in Russia and the Czech Republic }\end{array}$ & Bruce Kogut and Andrew Spicer & Feb. 2001 \\
\hline $\begin{array}{l}\text { No. } 291 \text { Institutional Technology and the Chains of Trust: Capital } \\
\text { Markets and Privatization in Russia and the Czech Republic }\end{array}$ & Bruce Kogut and Andrew Spicer & Mar. 1999 \\
\hline No. 290 Banking Crises and Bank Rescues: The Effect of Reputation & Jenny Corbett and Janet Mitchell & Jan. 2000 \\
\hline $\begin{array}{l}\text { No. } 289 \text { Do Active Labor Market Policies Help Unemployed Workers to } \\
\text { Find and Keep Regular Jobs? }\end{array}$ & Jan C. van Ours & Feb. 2000 \\
\hline No. 288 Consumption Patterns of the New Elite in Zimbabwe & Russell Belk & Feb. 2000 \\
\hline $\begin{array}{l}\text { No. } 287 \text { Barter in Transition Economies: Competing Explanations } \\
\text { Confront Ukranian Data }\end{array}$ & $\begin{array}{l}\text { Dalia Marin, Daniel Kaufmann } \\
\text { and Bogdan Gorochowskij }\end{array}$ & Jan. 2000 \\
\hline $\begin{array}{l}\text { No. } 286 \text { The Quest for Pension Reform: Poland's Security through } \\
\text { Diversity }\end{array}$ & $\begin{array}{l}\text { Marek Góra and Michael } \\
\text { Rutkowski }\end{array}$ & Jan. 2000 \\
\hline No. 285 Disorganization and Financial Collapse & $\begin{array}{l}\text { Dalia Marin and Monika } \\
\text { Schnitzer }\end{array}$ & Oct. 1999 \\
\hline No. $284 \mathrm{Coo}$ & $\begin{array}{l}\text { Yingyi Qian, Gérard Roland and } \\
\text { Chenggang Xu }\end{array}$ & May 1999 \\
\hline $\begin{array}{l}\text { No. } 283 \text { Why Russian Workers Do Not Move: Attachment of Workers } \\
\text { Through In-Kind Payments }\end{array}$ & Guido Friebel and Sergei Guriev & Oct. 1999 \\
\hline No. 282 Lessons From Fiascos in Russian Corporate Governance & $\begin{array}{l}\text { Merritt B. Fox and Michael A. } \\
\text { Heller }\end{array}$ & Oct. 1999 \\
\hline $\begin{array}{l}\text { No. } 281 \text { Income Distribution and Price Controls: Targeting a Social } \\
\text { Safety Net During Economic Transition }\end{array}$ & $\begin{array}{l}\text { Michael Alexeev and James } \\
\text { Leitzel }\end{array}$ & Mar. 1999 \\
\hline $\begin{array}{l}\text { No. 280: Starting Positions, Reform Speed, and Economic Outcomes in } \\
\text { Transitioning Economies }\end{array}$ & William Hallagan and Zhang Jun & Jan. 2000 \\
\hline No. 279: The Value of Prominent Directors & $\begin{array}{l}\text { Yoshiro Miwa \& J. Mark } \\
\text { Ramseyer }\end{array}$ & Oct. 1999 \\
\hline No. 278: The Sys & János Kornai & Apr. 1998 \\
\hline $\begin{array}{l}\text { No. 277: The Developmental Consequences of Foreign Direct } \\
\text { Investment in the Transition from Socialism to Capitalism: The } \\
\text { Performance of Foreign Owned Firms in Hungary }\end{array}$ & Lawrence Peter King & Sept. 1999 \\
\hline $\begin{array}{l}\text { No. 276: Stability and Disorder: An Evolutionary Analysis of Russia's } \\
\text { Virtual Economy }\end{array}$ & $\begin{array}{l}\text { Clifford Gaddy and Barry W. } \\
\text { Ickes }\end{array}$ & Nov. 1999 \\
\hline $\begin{array}{l}\text { No. 275: Limiting Government Predation Through Anonymous } \\
\text { Banking: A Theory with Evidence from China. }\end{array}$ & $\begin{array}{l}\text { Chong-En Bai, David D. Li, } \\
\text { Yingyi Qian and Yijiang Wang }\end{array}$ & July 1999 \\
\hline No. 274: Transition with Labour Supply & Tito Boeri & Dec. 1999 \\
\hline $\begin{array}{l}\text { No. 273: Sectoral Restructuring and Labor Mobility: A Comparative } \\
\text { Look at the Czech Republic }\end{array}$ & Vit Sorm and Katherine Terrell & Nov. 1999 \\
\hline $\begin{array}{l}\text { No. 272: Published in: Journal of Comparative Economics "Returns to } \\
\text { Human Capital Under the Communist Wage Grid and During the } \\
\text { Transition to a Market Economy" Vol. 27, pp. 33-60 1999. }\end{array}$ & $\begin{array}{l}\text { Daniel Munich, Jan Svejnar and } \\
\text { Katherine Terrell }\end{array}$ & Oct. 1999 \\
\hline $\begin{array}{l}\text { No. 271: Barter in Russia: Liquidity Shortage Versus Lack of } \\
\text { Restructuring }\end{array}$ & $\begin{array}{l}\text { Sophie Brana and Mathilde } \\
\text { Maurel }\end{array}$ & June 1999 \\
\hline $\begin{array}{l}\text { No. 270: Tests for Efficient Financial Intermediation with Application to } \\
\text { China }\end{array}$ & Albert Park and Kaja Sehrt & Mar. 1999 \\
\hline
\end{tabular}

